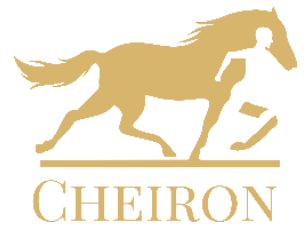

Cheiron: The International Journal of

Equine and Equestrian History

Vol. 1, Issue 1/2021

(C) The Authors 2021

Available online at

http://trivent-publishing.eu/

\title{
What Makes a Horse a Horse? \\ Configurational Aspects of Ancient Egyptian Equines
}

\author{
Lonneke Delpeut
}

\begin{abstract}
We expect depictions of things we know to contain certain elements. These elements depend on our experience, our visual requirements, culture, upbringing, and so on. For example, in order to recognise a certain subject, a degree of realism is expected. If these requirements are not met, either we are unable to correctly identify the subject as the intended subject, or we project our expectations and attribute the lack thereof as mistakes, inabilities, or lack of knowledge of the author. This bias is predominantly present in the analysis of ancient Egyptian images (and texts, for that matter) and is inappropriate. In order to correctly understand the intentions of the creator and the image, we need to understand their cultural properties, their pictorial system, and, most importantly, the function of the image. This article will look at depictions of horses from ancient Egypt, taking their function as a starting point, and discuss their configurational aspects in terms of the function of the image.
\end{abstract}

\section{Keywords}

Ancient Egypt; art history; image composition; significant attributes; images; horses.

DOI: 10.22618/TP.Cheiron.20211.1.233001

CHEIRON is published by Trivent Publishing

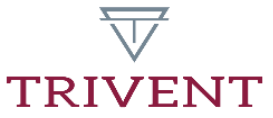

This is an Open Access article distributed in accordance with the Creative Commons Attribution Non Commercial (CC$B Y-N C$-ND 4.0) license, which permits others to copy or share the article, provided original work is properly cited and that this is not done for commercial purposes. Users may not remix, transform, or build upon the material and may not distribute the modified material (bttp:/ / creativecommons.org/ licenses/by-nc/4.0/) 


\title{
What Makes a Horse a Horse? \\ Configurational Aspects of Ancient Egyptian Equines
}

\author{
Lonneke Delpeut ${ }^{1}$
}

\begin{abstract}
We expect depictions of things we know to contain certain elements. These elements depend on our experience, our visual requirements, culture, upbringing, and so on. For example, in order to recognise a certain subject, a degree of realism is expected. If these requirements are not met, either we are unable to correctly identify the subject as the intended subject, or we project our expectations and attribute the lack thereof as mistakes, inabilities, or lack of knowledge of the author. This bias is predominantly present in the analysis of ancient Egyptian images (and texts, for that matter) and is inappropriate. In order to correctly understand the intentions of the creator and the image, we need to understand their cultural properties, their pictorial system, and, most importantly, the function of the image. This article will look at depictions of horses from ancient Egypt, taking their function as a starting point, and discuss their configurational aspects in terms of the function of the image.
\end{abstract}

\section{Keywords}

Ancient Egypt; art history; image composition; significant attributes; images; horses.

\section{Introduction}

Ancient Egyptian images are a well-studied phenomenon. Many of us will be familiar with the paintings and reliefs that adorn tomb and temple walls, giving us a visual impression of certain aspects of ancient Egyptian culture. Every image, however, is made with a purpose. Depending on the function, location and target audience of the image, it adheres to a certain theme, canon and decorum. With this in mind, the current article will take a look at twodimensional depictions of horses in private tombs, with the aim to understand how the ancient Egyptians formatted their images to be understood.

First, this article will give an overview of the history of the study of the horse in ancient Egypt. It will briefly introduce the different facets of the horse in terms of osteological remains, the horse in text, the horse in material culture and the horse in two-dimensional representations. Secondly, it will show the different approaches applied in the past to study the images of the horse. The process of looking for, and recognising modern concepts, ideas

\footnotetext{
1 University of Vienna, Austria.
} 
and customs in ancient depictions is called "retrojection," 2 and should not be encouraged. The practice of retrojection is rather common in animal studies, as we often look for explanations as to why subjects are depicted a certain way. Instead, this article aims to show why things are depicted as they are depicted by showing that art-historical considerations are the key to understanding how these images work. Finally, it will give some new insights into the two-dimensional renderings of horses, discussing attributes like coat colour, posture, behaviour and movement, taking the function of the image as a starting point.

\section{The horse in ancient Egypt}

The introduction of the horse in ancient Egypt occurred somewhere during the so-called Second Intermediate Period (1759-ca. 1539 BCE). ${ }^{3}$ With this, Egypt was relatively late to the party. It has long been speculated that, unlike the Egyptians, the Hyksos possessed horses, which supposedly caused a military advancement big enough to take over power in Egypt. This theory has been refuted in the meantime. ${ }^{4}$ The exact process of the introduction of the horse in ancient Egypt remains speculative to this day. The 2003 article by Miriam Bibby ${ }^{5}$ is to this date the most comprehensive article about the arrival of the horse in Egypt, as it looks at the material taking her knowledge of horses as the leading perspective. For those studying the horse in ancient Egypt, Ulrich Hofmann's dissertation is not to be missed. ${ }^{6}$ More recently, Susan Turner has finished her dissertation on the horse in ancient Egypt, discussing the horses' nature, role and impact in ancient Egypt. ${ }^{7}$

The horse and the chariot are inextricably linked in ancient Egypt. Mary Aiken Littauer and Joost Crouwel published the go-to reference on chariots in ancient Egypt as well as the Near East ${ }^{8}$ as well as the chariots found in the tomb of pharaoh Tutankhamun. ${ }^{9}$ More recently are the publications by André Veldmeijer and Salima Ikram about the Tano Chariot ${ }^{10}$ and the proceedings of the First International Chariot Conference ${ }^{11}$ which took place in Cairo 2012. Both publications are a collection of papers by authors trained in various disciplines,

\footnotetext{
2 Peter Webb, Imagining the Arabs: Arab Identity and the Rise of Islam (Edinburgh: Edinburgh University Press, 2014).

${ }^{3}$ All dates in this article are based on the publication by Erik Hornung, Rolf Krauss, and David A. Warburton, Ancient Egyptian Chronology (Leiden: Brill, 2006).

${ }^{4}$ Chris Stantis, Awara Kharobi, Nina Maaranen, Geoff M. Nowell, Manfred Bietak, Silvia Prell, Holger Schutkowski, "Who Were the Hyksos? Challenging Traditional Narratives Using Strontium Isotope (87Sr/86Sr) Analysis of Human Remains from Ancient Egypt," PLoS ONE 15(7) (2020): e0235414.

${ }^{5}$ Miriam Bibby, "The Arrival of the Horse in Egypt: New Approaches and a Hypothesis," in Current Research in Egyptology III: December 2001, ed. Rachel Ives, Daniel Lines, Christopher Naunton, Nina Wahlberg (Oxford: Archaeopress, 2003), 13-18.

${ }^{6}$ Ulrich Hofmann, Fubrwesen und Pferdebaltung im alten Ägypten (Bonn: Rheinische Friedrich-WilhelmsUniversität Bonn, 1989).

${ }^{7}$ Susan P. Turner, "The Horse in New Kingdom Egypt: Its Introduction, Nature, Role and Impact," $\mathrm{PhD}$ Thesis, Macquarie University, Sydney (2015).

${ }^{8}$ Mary A. Littauer, Joost H. Crouwel, Selected Writings on Chariots and Other Early Vehicles, Riding and harness (Brill: Leiden, 2002).

${ }^{9}$ Mary A. Littauer, Joost H. Crouwel, Chariots and Related Equipment From the Tomb of Tut'ankhamuin (Oxford: Griffith Institute, 1985).

10 André J. Veldmeijer, Salima Ikram, eds., Chariots in Ancient Egypt: The Tano Chariot, a Case Study (Leiden: Sidestone Press, 2018). This publication is freely available online on the Sidestone website.

11 André J. Veldmeijer, Salima Ikram, eds., Chasing Chariots: Proceedings of the First International Chariot Conference (Cairo 2012) (Leiden: Sidestone Press, 2013). This publication is freely available on the Sidestone website.
} 
offering a multidisciplinary treatment of the ancient Egyptian chariot. Currently working on the golden pieces of the harness of pharaoh Tutankhamun are Christian Eckmann and Katja Broschat, who study their material composition, and Julia Bertsch who is working on the iconography on the gold sheet appliqués. A preliminary report was published in 2017.12

Osteological remains of horses from ancient Egypt are scarce. This seems to contradict the many depictions and texts from (among others) the New Kingdom (1549-1077 BCE), displaying the amounts of horses taken captive during battle. An example is the booty of war of Thutmose III, mentioning 2041 horses, 191 foals, 6 stallions and [a number of $]^{13}$ colts. $^{14}$ Several reliefs of the battle of Kadesh show horses being involved in battle. ${ }^{15}$ Horses being traded in the ancient Near East is a known phenomenon, supported by several AmarnaLetters. ${ }^{16}$ Despite these accounts, archaeologists have not managed to find the amounts mentioned by the Egyptians. Louis Chaix ${ }^{17}$ gives a brief overview of almost all horse remains found in Egypt, which add up to about two handfuls. Most notably is the so-called Buhen horse, dating from the New Kingdom, buried in Middle Kingdom debris in the fortress of Buhen in Southern Egypt. ${ }^{18}$ Recent finds include a horse found in the royal palace in Avaris, the Hyksos capital, and it should come to no surprise that this is one of the oldest remains found in Egypt. ${ }^{19}$ One set of remains that is accessible to this date are the remains of a horse found in the forecourt of Theban Tomb 71, tomb of Senenmut. ${ }^{20}$ This horse was wrapped in linen, accompanied by a linen cloth on its back and buried in a wooden coffin. A very recent find in Tombos, Sudan uncovered an unexpected find of a horse whose skeleton was found in perfect condition. ${ }^{21}$ Unfortunately none of the remains found in Egypt or Sudan have resulted in successful DNA results.

The first indisputable textual evidence of horses in ancient Egypt can be found in the tomb of Ahmose, son of Ebana in el Kab. This tomb dates from the time of pharaoh Thutmose I (1493-1483 BCE) and shows the very first known hieroglyphs of a horse as well as that of a chariot (fig. 1.a-b). The text tells us that Ahmose captured a chariot during one of

${ }^{12}$ Julia Bertsch, Katje Broschat, Christian Eckmann, "Kairo, Ägypten. Die Goldblechbeschläge aus dem Grab des Tutanchamun,“ iDai.publications 1 (2017): 54-57.

${ }^{13}$ Lacuna in text.

${ }^{14}$ Kurt Heinrich Sethe, Urkunden der 18. Dynastie: Historisch-Biographische Urkunden, dritter Band (Leipzig: Hinrichs, 1906), 663.

${ }^{15}$ See for example the Karnak hypostyle hall or the Ramesseum, e.g.: Heinz, Susanna Constanze, Die Feldzugsdartstellungen des Neuen Reiches: Ein Bildanalyse (Vienna: Verlag der Österreichischen Akademie der Wissenschaften: 2001) 292.

${ }^{16}$ For example, EA7, EA9, EA15, EA16, EA17, EA19, EA22, EA34 and EA37, translated and published by William L. Moran, The Amarna Letters (Baltimore: The Johns Hopkins University Press, 1992).

${ }^{17}$ Louis Chaix, "An Hyksos Horse from Tell Heboua," in Archaeozoology of the Near East IV, ed. Marjan Mashkour (Archaeological Research and Consultancy: Paris, 1998), 177-186.

${ }^{18}$ Juliet Clutton Brock, Peter Raulwing, "The Buhen Horse: Fifty Years after Its Discovery (19582008)," Journal of Egyptian Archaeology 2 (2009): 1-106.

${ }^{19}$ Manfred Bietak, "Le Hyksos Khayan, son Palais et une lettre en cuneiforme," Comptes rendus des séances de l'Académie des Inscriptions et Belles-Lettres 2 (2010): 973-990. For a picture of the horse, see: www.researchgate.net/publication/319648542_What_is_a_horse_Lexical_Acculturation_and_Classifi cation_in_Egyptian_Sumerian_and_Nahuatl_Sources_Methods_and_Theories_from_an_Interdiscipli nary_Perspective/figures?lo=1.

20 Ambrose Lansing, William C. Hayes, “The Museum's Excavation at Thebes,” The Metropolitan Museum of Art Bulletin, 32: 1, Part 2: The Egyptian Expedition 1935-36 (Jan. 1937): 4-39.

${ }^{21}$ Sarah A. Schrader, Stuart Tyson Smith, Sandra Olsen, Michele Buzon, "Symbolic Equids and Kushite State Formation: A Horse Burial at Tombos," Antiquity 92: 362 (2018): 383-397. 
the campaigns of Thutmose I and showed it to the pharaoh later. The pharaoh rewarded Ahmose for bringing him the chariot for a bundle of gold. ${ }^{22}$ Earlier textual evidence is suggested on the so-called Kamose stela, dating from the late Seventeenth dynasty, where the word "Htr" is used. This is translated as "chariot-team," 23 or "chariotry," 24 and is determined with the hieroglyph for animal skin (F27), not with a horse hieroglyph. The animal skin hieroglyph indicates it is meant to be interpreted as some kind of vehicle pulled by animals and is often attributed as the earliest word for "chariot" in ancient Egypt. The word for horse is ssm.t, definitely a loanword, probably imported from Ugaritic or another neighbouring Semantic language. It is mostly determined with the hieroglyph for "horse." Ancient Egyptian horse related terminology is extensively discussed by Pascal Vernus' article published in $2009 .{ }^{25}$

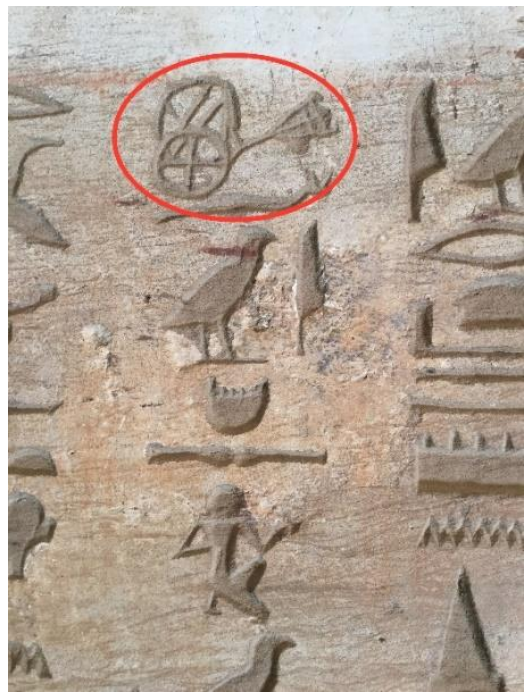

Fig. 1.a: The earliest known hieroglyph of a chariot. Location: The tomb of Amose, son of Ebana in El Kab. Photo: L.P.P. Delpeut.

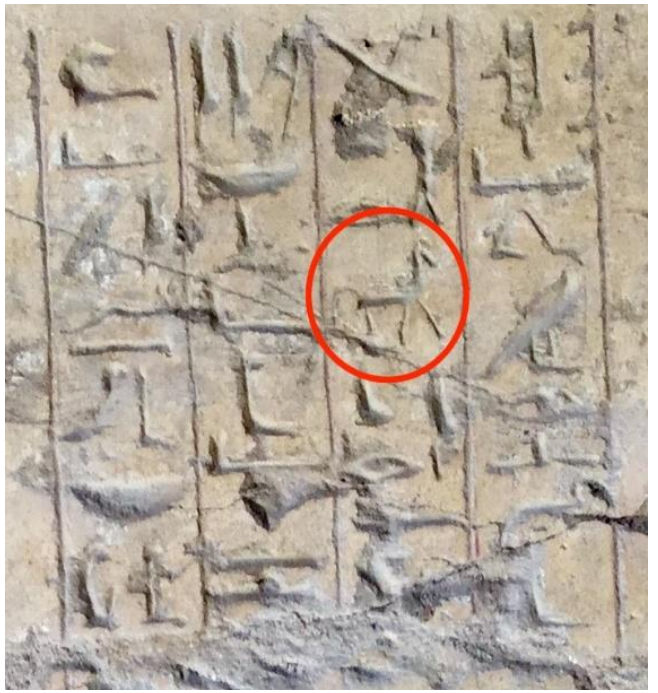

Fig. 1.b: The earliest known hieroglyph of a horse. Location: The tomb of Amose, son of Ebana in El Kab. Photo: L.P.P. Delpeut.

\section{The horse in imagery}

Since there are so little osteological remains to work with, scholars have to use other media to study what horses looked like, of which images are the most evident. The earliest known

\footnotetext{
22 Kurt Heinrich Sethe, Urkunden der 18. Dynastie: Historisch-Biographische Urkunden, erster Band (Leipzig: Hinrichs, 1927), 219.

${ }^{23}$ William Kelly Simpson, The Literature of Ancient Egypt (Yale: Yale University, 2003), 346.

${ }^{24}$ Labib Habachi, The Second Stela of Kamose, and His Struggle Against the Hyksos Ruler and His Capital (Glückstadt: J.J. Augustin, 1972), 36.

25 Pascal Vernus, "Réception linguistique et idéologie d'une nouvelle technologie: le cheval dans la civilisation pharaonique," in Miriam Wissa (ed.), The Knowledge Economy and Technological Capabilities: Egypt, the Near East and the Mediterranean 2nd Millennium B.C. - 1st millennium A.D. Proceedings of a Conference beld at the Maison de la Chimie Paris, France 9-10 December 2005 (Barcelona: Sabadell, 2009), 1-46.
} 
image of a horse is found in the pyramid temple of Ahmose in Abydos, excavated and published by Stephen Harvey. ${ }^{26}$ The relief shows a pair of harnessed horses in resting position, likely attached to a chariot. The colour of the horses clearly seems to be chestnut, a colour that turns out to be the one most frequently used for the depictions of horses. Other reliefs from the same temple were reconstructed by Harvey as battle reliefs, resulting in several pairs of horses in front of chariots charging at the enemy. ${ }^{27}$ Considering the context of these images, namely royal iconography, it is no wonder that many of the images show the horses in their main function, namely in front of chariots involved in battle. For a reference on the role of the horse in military context, see Anthony Spalinger's publication War in Ancient Egypt. ${ }^{28}$ Most depictions of horses show them in front of or in relation to a chariot, but there are also some depictions of horses being ridden. The most famous example is that from the tomb of Horemheb, fig. X. Due to the lack of depictions of horse riders, scholars have often assumed this was not a common practise in ancient Egypt. Alan Schulman believes depicted riders are supposed to be interpreted as mounted scouts, a "small but important branch of the Egyptian army in the New Kingdom..$^{29}$ In his article, he gives an overview of all known depictions of horse riders and stresses the advantage of riding over driving: he retained speed and mobility. ${ }^{30}$

Catherine Rommelaere is one of the few authors who published a book on the horse in Ancient Egypt in 1991. ${ }^{31}$ She treats their origins, their breeds and their harness, and her book is a great reference for an overview of images of horses in ancient Egypt. Her iconographic analysis however leaves room for improvement. Rommelaere claims to recognise two different breeds of horses at the beginning of the Eighteenth dynasty (1539-1483 BCE) based on their visual characteristics. ${ }^{32}$ Her two categories are "longligne," which she links to the Przewalski horse, and "brèveligne," which she links to the Tarpan horse. ${ }^{33}$ She then compares the remains of the Buhen horse and the horse found in the forecourt of Senenmut to early Eighteenth dynasty depictions and concludes that based on their size and osteological features they "coincide perfectly." 34 Additionally, she compares horse remains found in Soleb dating to the reign of Amenhotep III (late Eighteenth dynasty) to images of the same time period and concludes that these remains are much larger and therefore correspond to the second type (brèveligne). Since according to her the bones are comparable to the images from the same time periods, she supposes that the images are "an exact reflection of reality." 35 There are several problems with this assessment. First, one cannot assume that any features of twodimensional depictions are in general "naturalistic" without taking into consideration the function of the image. The shape and posture of the horse are dependent on the artist's perception, skillset, artistic conventions and personal style, among other things. The reason

\footnotetext{
26 Stephen Harvey, "Monuments of Ahmose at Abydos," Egyptian Archaeology 4 (1994) 3-5.

${ }^{27}$ See Anthony J. Spalinger, War in Ancient Egypt: The New Kingdom (Oxford: Blackwell Publishing, 2005) for the publication of the image and line drawings of the reliefs (pp. 20-21) as well as the reconstruction (p. 22).

28 Anthony J. Spalinger, War in Ancient Egypt.

${ }^{29}$ Alan R. Schulman, "Egyptian Representations of Horsemen and Riding in the New Kingdom," Journal of Near Eastern Studies 16: 4 (1957): 263.

30 Schulman, "Egyptian Representations of Horsemen and Riding in the New Kingdom," 264.

31 Catherine Rommelaere, Les Cheveaux du Nouvel Empire Égyptien: Origines, races, harnachement (Brussels: Connaissance de l'Égypte ancienne, 1991).

32 Ibidem, 34-37.

33 Ibidem, 38.

34 Ibidem, 40.

35 Ibidem.
} 
the horses are depicted the way they are might not have anything to do with how they look "in real life," as this article will show. Secondly, her bipartite division does not do justice to the different "types" of horses, as she calls them. From an iconographic viewpoint, one is able to distinguish many more "types" based purely on visual characteristics, as we will see later. Lastly, it is hardly scientifically sound to base conclusions on the origin of the horse on the scarce amount of osteological remains we have. They are far from representative in terms of statistics. Additionally, recent studies have shown that the Przewalski horse is not related to any of our modern horse breeds. ${ }^{36}$ Drawing parallels with the Egyptian horses, whether based on non-invasive analysis of osteological remains or two-dimensional depictions is therefore not justifiable.

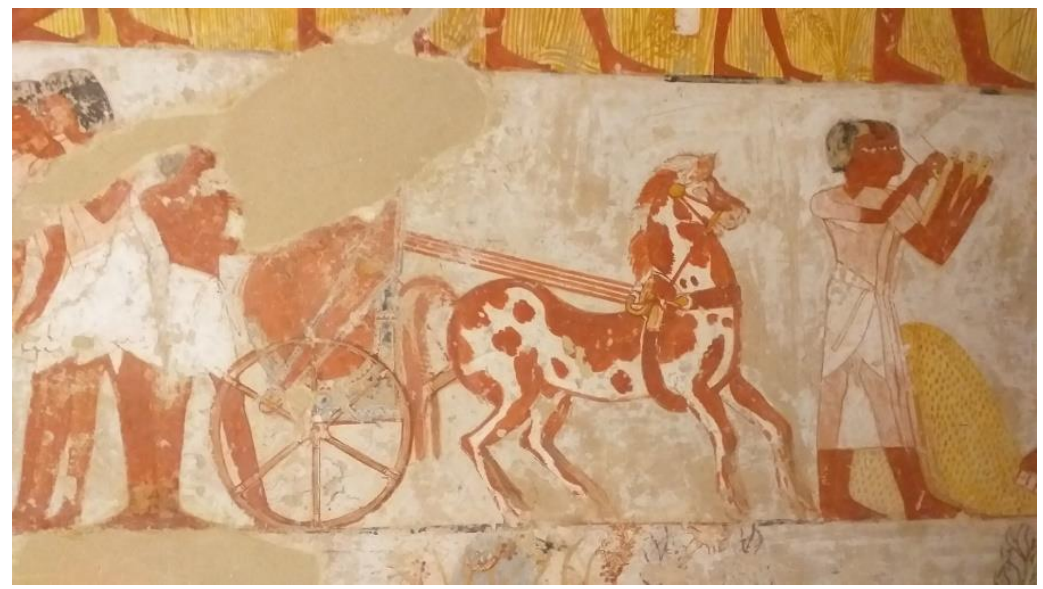

Fig. 2. Two horses in TT69, tomb of Menna.

Location: Sheikh Abd el-Qurna, Thebes. Photo: JJ Shirley.

Animal publications often use depictions of animals in ancient Egypt as one of their primary sources of what they looked like, and subsequently what kind of breed or sub-breed they are supposed to represent. With some animals, like birds and fish, this is more likely to be true than with others as their colours and attributes are rather indicative of what species they belonged to. In the case of horses, however, this is less evident. Whereas colours of horses can indicate a certain breed, albeit rarely, ${ }^{37}$ the Egyptian images do not possess enough defining attributes to assign them to a certain breed or type. The images of ancient Egyptian horses are often compared to the modern Arabian horse. Their exaggerated features, as visible in fig. 2, correspond to an extent to the visual characteristics of the Arabian horse. These features, combined with the small stature of the few horse remains that were found, are often compared to the modern Arabian horse. The current author and her colleague Hylke Hettema have explained in their article "From Ancient Egyptians to Modern Arabians: A reinterpretation of Evidence" that this comparison purely based on imagery is not adequate.

\footnotetext{
${ }^{36}$ Ludovic Orlando, Alan K. Outram, e.a., "Ancient Genomes Revisit the Ancestry of Domestic and Przewalski's Horses,” Science 360: 6384 (April 2018): 111-114.

${ }^{37}$ For example, the modern Paint breed needs a certain pattern, whereas this is not allowed in the modern Arabian horse.
} 
Seeing the ancient Arabian horse in the ancient Egyptian images is the epitome of retrojection, as we explain in the aforementioned article. ${ }^{38}$

\section{A. Some theory}

Depictions in ancient Egypt depend on several factors, for example, their location, their intended message, their function, the artisan's skillset, their target audience, and so on. The Egyptian artisan had to work within the unwritten customs that informed their visual culture. These customs work twofold, namely in terms of format, ${ }^{39}$ and it terms of content; ${ }^{40}$ in other words, how subjects are depicted and what is depicted. Depending on the location of the depictions, certain themes are appropriate where others are not. The same goes for format as there are certain elements that are off-limits, often related to the recognisability of the subject. For example, there were no images of purple horses found in ancient Egypt. All images contain so-called "significant attributes", which are those elements considered essential for the correct identification of the culturally defined category represented by the figure. ${ }^{41} \mathrm{In}$ other words, significant attributes are whatever elements are needed for the audience to recognise a house as a house, a tree as a tree, or in our case, a horse as a horse. Without these elements, one would not be able to recognise the depicted subject correctly. This means that, in principle, the artisan has a certain freedom he can work within, as long as the subject is recognisable. It also means that a certain level of naturalism is expected to resemble the depicted subject. The current author therefore assumes that all images are based on reality, but it is the question to what extent they convey reality.

\section{B. The horse as a concept}

Egyptian depictions are often described as "generic" due to the uniformity in display. To an extent, this is true: there are many aspects that are common in the display of subjects. Representations seem to be classified in categories rather than in specific subjects, for example, the image of a horse represents the category of a horse rather than a specific horse. The function of the horse within the image is in most cases not to display a specific animal, but rather to show a representation of "the horse" in general. This way of displaying subjects is called conceptual display, and is in ancient Egypt characterised by the uniformity of display in the imagery and by the fact that in most cases the visual characteristics of a subject renders the observer unable to identify which specific subject is meant to be displayed. In most cases therefore, an image of a horse is just that, "a" horse.

\section{The function of the image}

The scope of this research investigates the function of the image of the horse in private tomb chapels in ancient Egypt, which is where most discussed material will come from. Private

\footnotetext{
38 Linda Evans, Animal Behaviour in Egyptian Art: Representations of the Natural World in Memphite Tomb Scenes (Oxford: Aris and Phillips, 2010), 2, 10.

39 This is called 'canon'. For more information, see Whitney Davis, The Canonical Tradition in Ancient Egyptian Art (Cambridge: Cambridge University Press, 1989).

40 This is called 'decorum'. For more information, see John Baines, Visual and Written Culture in Ancient Egypt (Oxford: Oxford University Press, 2007).

${ }^{41}$ Kent Weeks, "Art, Word, and the Egyptian World View," in Egyptology and the Social Siences: Five Studies, ed. Kent Weeks (Cairo: American University in Cairo Press, 1979), 65.
} 
tombs consisted of three parts, ${ }^{42}$ of which only the tomb chapel is relevant for this research as that is where the images are placed. These tomb chapels were open to the public, with a specific audience in mind. Hartwig describes that the function of tomb decoration is twofold: To project the identity of the deceased into the afterlife as well as to commemorate it among the living who visited the tomb, and to visually reinforce society's cultural identity. ${ }^{43}$ The tomb owner was hoping to impress his peers with the images which would result in a contribution to his cult so that he was provided with provisions in the afterlife. They also aimed to convey the status of the tomb owner by showing on different levels how important he was, especially in relation to the king. As to the function of the individual scenes and images, they aim to convey a certain message. Their aim is not to display their depicted subjects as they are in 'real life', which is why when we are looking for "realism" or "naturalism," there might not be any. The images represent a concept of the depicted subject, and use certain attributes to convey things like movement, coat colours, behaviour and posture. We will see below how the ancient Egyptian artisans used these attributes to convey these concepts, not always meeting our modern expectations. This article will show how the function of the image is still met, despite the images' lack of relationship to realism and naturalism.

\section{A development through time}

The realm the artisan worked within becomes clear when studying the development of the image of the horse in ancient Egypt. Instead of Rommelaere's interpretation of attributing the difference in depiction to different types of horses, it is rather explained by a change in depiction as a result of the development of the image of the horse. For the purpose of this paper, there are three different time periods in the Eighteenth dynasty considering the horse. The early Eighteenth dynasty lasts from the first pharaoh of the dynasty until the reign of Thutmose III (1539-1480 BCE). The Mid-Eighteenth dynasty lasts from Thutmose III until Amenhotep II (1479-1390 BCE), as there was a large influx of horses into Egypt in this time period. From Amenhotep III onwards, the horse and chariot are part of the Egyptian military, and will be the Late Eighteenth dynasty (1390-1292 BCE).

In the Early Eighteenth dynasty, the horse is introduced as a new animal to the Egyptian canon and decorum (for example, see fig. 3). In order for the audience to recognise a new subject, it had to correspond to certain expectations of the visitor. Instead of interpreting the shape of the depictions of horses in images from this period as an accurate representation of what horses looked like, it is more likely that its initial formatting had to do with meeting these expectations. The process of recognising a subject by comparing it to something one knows, is what John Baines calls a "psychological parallel." 44 This happens every day when we look into the kitchen and recognise a "stove," "pan," "sink," etc. Baines also mentions that the creation of a representational form at the initial devising of a suitable form is difficult. The [psychological] parallel may also suggest a model for the communicative aspect of representation, whose principal purpose is to stimulate a recognition for the viewer. 'Recognition may be triggered by a minimal 'likeness,' which is primarily the likeness of a class or concept." 45 In other words, in order recognise something new, it helps for the depiction to look like something one already knows, in the case of the horse for example, it

\footnotetext{
${ }^{42}$ Friederike Kampp, Die Thebanische Nekropole: Zum wandel des Grabgedankens von der XVII. bis zur XX. Dynastie (Mainz am Rhein: Verlag Philipp von Zabern, 1996), 8.

43 Melinda Hartwig, Tomb Painting and Identity in Ancient Thebes, 1419-1372 BCE (Brussels: Brepols, 2004), $5-21$.

44 John Baines, Visual and Written Culture (Oxford: Oxford University Press, 2007), 212.

${ }_{45}$ Baines, Visual and Written Culture, 212.
} 
could be the donkey. The way a group of horses is shown closely resembles the depiction of a lot of other quadrupeds, going as far back as the Old Kingdom. When comparing the image of the horse to that of the donkey at the beginning of the Eighteenth dynasty, this seems to be exactly what happened. In terms of formatting, shape, posture and grouping the animals, the similarities are clearly visible. So are the differences: the horses' ears are smaller, their manes lie flat in their necks, their colours are grey and chestnut and their tails are bushy and full, in contrary to donkeys. These differences, as well as the similarities, have been deliberately introduced. The artisan made sure you would recognise an equid in the similarities, but also made sure you would recognise the horse as its own being by giving it visual characteristics that correspond to what the observer was supposed to recognise as "horse." It is these differences that form the significant attributes of the horse at the beginning of the Eighteenth dynasty.

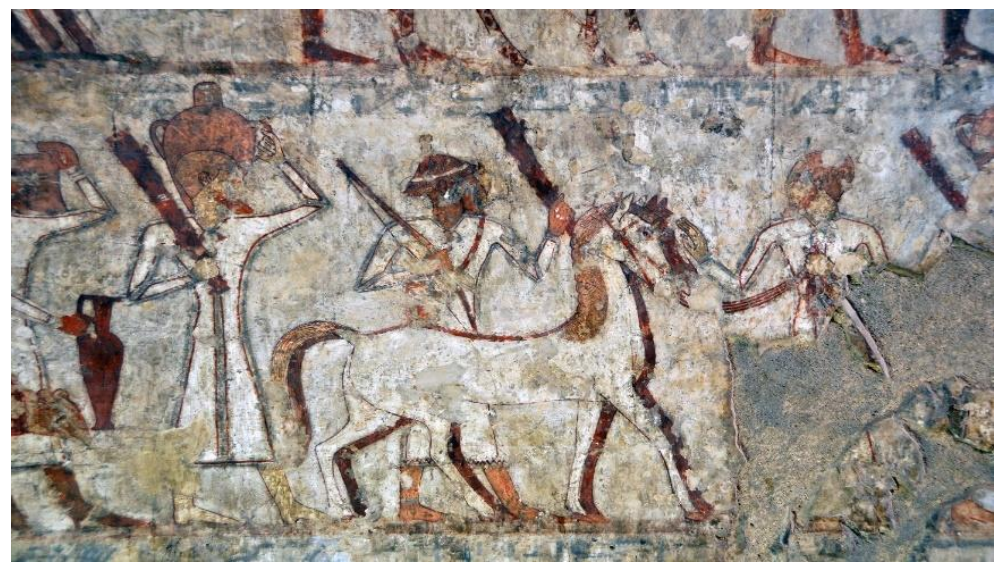

Fig. 3. Horses in TT100, tomb of Rekhmire. Location: Sheikh Abd el-Qurna, Thebes. Photo: A. Den Doncker.

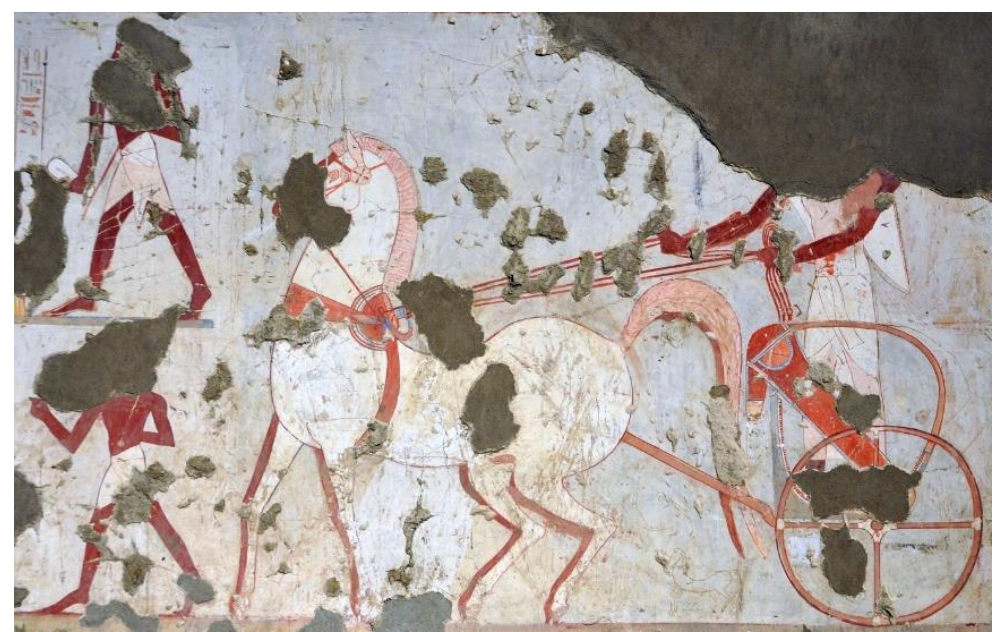

Fig. 4. Horses in TT75, tomb of Amenhotep-Sise. Location: Thebes. Photo: A. Den Doncker 
Towards the end of the reign of Thutmose III, the image of the horse starts to change. The initial, donkey-like representation of the horse has been the standard, and the observer now knows how to recognise the horse in two-dimensional imagery. As the audience is now able to recognise the horse as such, this means the formatting can change. It is only after the reign of Thutmose III that textual evidence suggests a large influx of horses into Egypt, after which it seems to become more common in Egyptian society. This is why in the MidEighteenth dynasty, the image of the horse starts to change. As the horse becomes a more common sight in Egyptian society, the formatting rules change for the artisan: more people will be able to recognise the horse, and can therefore take more freedom in creating the image. The horse does not need to look like the donkey anymore for the initial recognition of the audience and starts to develop into a subject with its own visual characteristics. The artisan clearly takes his newly found freedom to heart, as can be seen in TT69, the tomb of Menna (fig. 2), where certain features are exaggerated. The horses' chest is protruding severely, their backs are hollow and their hind quarters are disproportionally voluminous. Fig. 4 from TT75, the tomb of Amenhotep Sise shows an example where the shape is clearly not intended to portray naturalism, and clearly shows that "shape" no longer functions as a significant attribute. Their hollow backs and voluminous hind quarters make the image of the horse almost into a caricature. Despite the lack of naturalistic display in these images, they still serve their function: These animals are clearly meant to be interpreted as horses.

Another significant difference with the Early Eighteenth dynasty image is the display of the manes. Whereas in the Early Eighteenth dynasty the manes of the horses were still depicted flat in their neck, they now seem to be standing upright. It is unsure whether this displays a change in grooming, as it could also be simply a change in display. Horses' manes usually look like a full, uninterrupted bush, going from their ears all the way down to their withers. This uninterrupted flock of hair is easily displayed by a simple brush stroke on top of the horses' neck. Especially when horses move, their manes move and elevate from their necks; even if these horses had long manes, it could still seem like they're standing up. The Egyptians have a tendency to display objects frontally and completely, even though it is not realistic in real space, with the intention that the observer would be able to see the whole object. See for example fig. 5, where Horemheb's golden necklace is shown standing upright on the display platter. What is being conveyed here is that it is lying flat on the display platter. The aim of this way of showing the necklace is that the observer is able to see, and be impressed with, the whole necklace, something a "realistic" and flat display wouldn't have been able to do. It is likely that with displaying the horses' manes this way, the aim was similar. What needs to be mentioned of course is that short manes are much more practical for horses that pull chariots. The current author is not convinced however that even with short manes, those of the ancient Egyptian horses would have actually stood upright, as that only happens with certain horses with specifically thick manes.

Another interesting observation is that the colour coats are more variable. In the Early Eighteenth dynasty a pair of horses were often shown with a grey and a chestnut coat. This was likely done in order to distinguish the horses from donkeys, which were usually displayed with a light to dark grey and sometimes brown colour. In the Mid-Eighteenth dynasty a full array of colours can be seen, as for example in fig. 2, and fig. 6 .

By the time of Amenhotep III, chariotry is part of the Egyptian military, ${ }^{46}$ and the image of the horse has developed fully into its own character, as is visible in fig. 7. The artisans have found a status quo: the initial impression of the image seems more naturalistic and with less extreme features as they had in the Mid-Eighteenth dynasty. Around this time, a new equid

\footnotetext{
${ }^{46}$ Andrea M. Gnirs, Militär und Gesellschaft: Ein Beitrag zur Sozialgeschichte des Neuen Reiches (Heidelberg:
} Heidelberger Orientverlag, 1996). 
finds its way into the Egyptian imagery: the Persian onager. Four images of Persian onagers are known in private tombs, and interestingly enough, they are always juxtaposed to those of horses, as if the artisan is encouraging you to find the differences (fig. 7 and 8 for example). It seems that the image of the horse is so familiar in society, that it is now used to distinguish them from these new equids, similar to the function the images of donkeys had to horses in the Early Eighteenth dynasty, hence the juxtaposition.

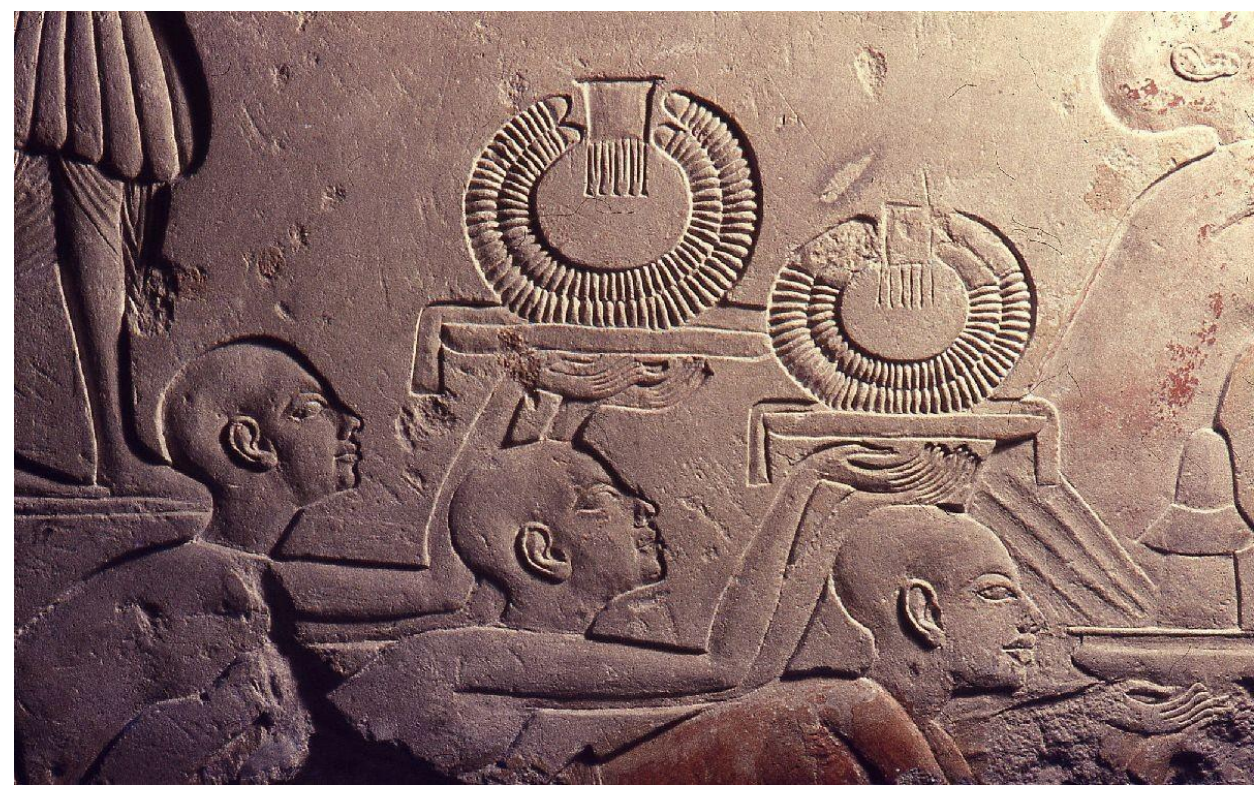

Fig. 5. Necklaces "standing upright" on a platter, from the tomb of Horemheb. Photo: Rijksmuseum van Oudheden, Leiden. Accession number: H.III.SSSS-b.

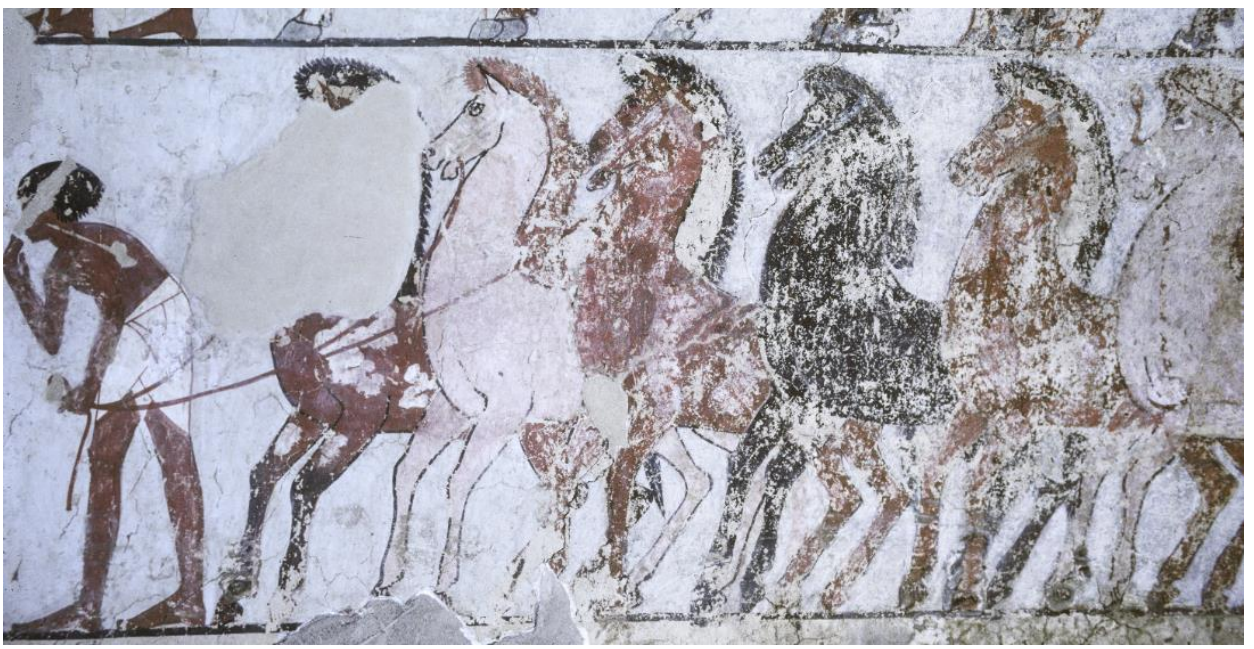

Fig. 6. Horses in TT74, tomb of Tjanuny. Location: Sheikh Abd el-Qurna, Thebes.

Photo: R.J. Demarée. 


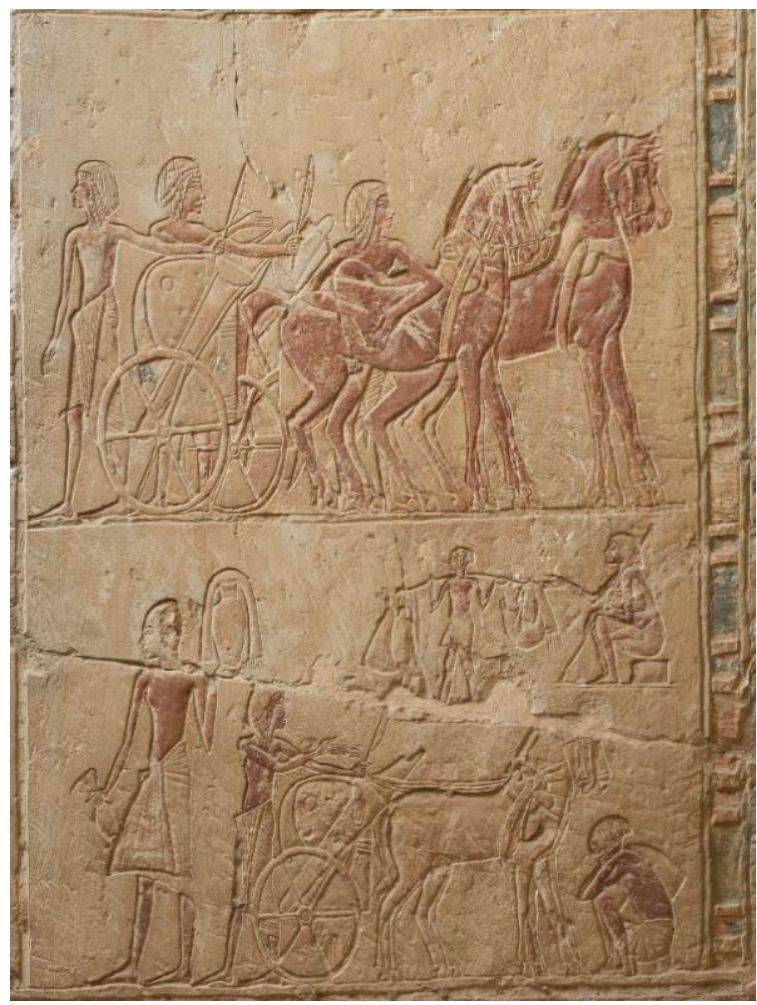

Fig. 7. Horses (above) and Persian onagers (below) in the tomb of Horemheb. Location: Saqqara. Photo: N. Dell'Aquila.

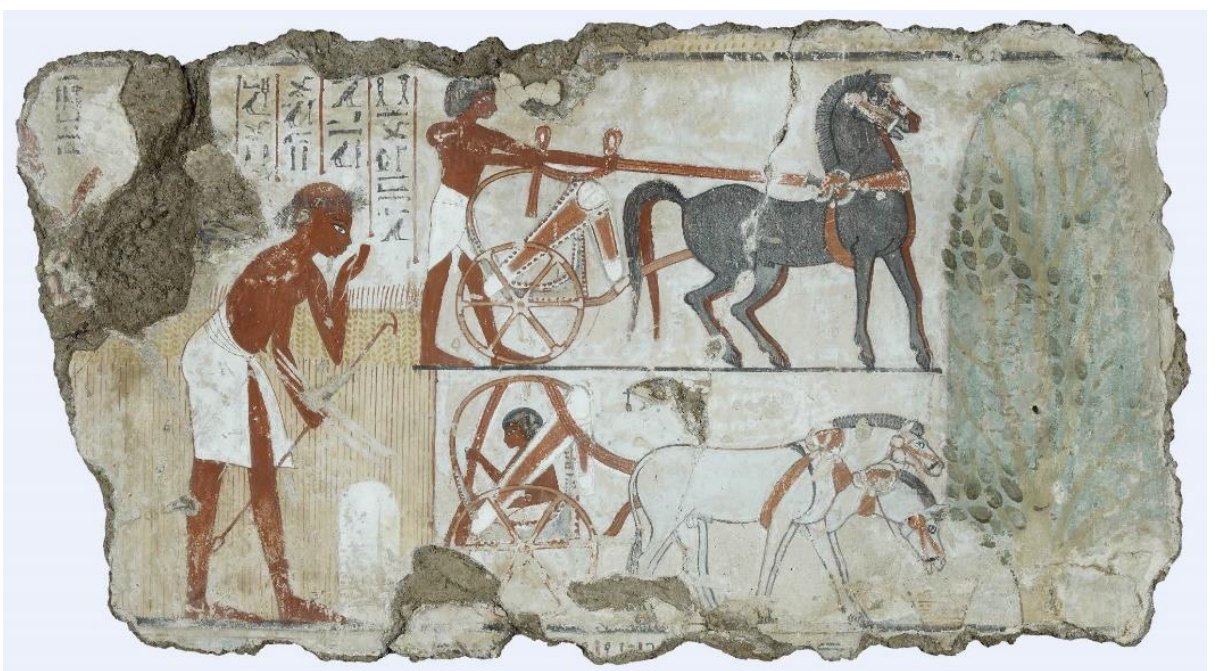

Fig. 8: Horses (above) and Persian onagers (below) from the tomb of Nebamun. Photo: (C) The Trustees of the British Museum. Accession number: EA 37982. 


\section{A. Horses versus other equids}

It is difficult to exactly determine the kind of equids in the lower register of fig. 8 based solely on their visual characteristics. Many authors have attempted to define the equid, calling them hinnies ${ }^{47}$ mules, ${ }^{48}$ and Przewalski horses ${ }^{49}$. For a complete discussion of the type of equid indicated in depiction, see 'Mules of the 18th dynasty' by Kathryn M. Hansen. ${ }^{50}$ Anthony Dent is the first one to identify them as "onagers (or mules by onager stallions)." 51 The argument for onagers is further supported by Hansen who identifies them as Persian onagers on the basis of conformation, shoulder stripe and coat colour..$^{52}$ As the current author does not have a better alternative, she will go with the interpretation of onagers.

The juxtaposition of the horses and onagers was quite carefully designed. In fig. 8 we can see that there is a clear difference in colour coat, physical features, genital sex markers, behaviour, posture, and even the behaviour of the groom. The horses have a dark grey and a liver chestnut colour coat, where the onagers are light grey with dark grey manes, corresponding more to the greyish colour coat of the donkey. The onagers' heads are very similar to the horses' heads, including the size of their ears, which is usually a clear differentiator between horses and donkeys. Their tails, however, are clearly more like the donkey tail. The behaviour of the animals is also rather distinct. Looking at the onagers' genital sex markers, these can be clearly identified as stallions. The horses show only a phallus sheath. This might seem coincidental, but rather it can be assumed that every depicted sex marker served a specific function in the image. The horses' behaviour seems giddy, and the groom is holding the reins rather tightly. Their heads are held high, and they seem ready for action; they do not at all seem relaxed. The onagers however are calmly eating or drinking from a trough, calm enough for the groom to casually hold the reins and sit down and not even face the animals he is taking care of. The differences are emphasised by juxtaposing the animals, and if they would have been depicted individually, the distinction between horses and onagers would not have been so evident, especially since onagers only occur in four Theban Tombs, suggesting they were uncommon in Egyptian society.

\section{Colours and patterns}

The images of horses in private tombs show a great variety of coat colours. In terms of colours we see grey, chestnut, bay, palomino, blue roan, and black, and in terms of patterns we see paint horses. ${ }^{53}$ As with any colour or pattern, the varieties of horses also depended on

\footnotetext{
${ }^{47}$ Juliet Clutton-Brock, Horse Power: A History of the Horse and the Donkey in Human Societies (Harvard: Harvard University Press, 1992), p. 86, fig. 6.8.

${ }^{48}$ Kenneth Kitchen, "prd > ptr = "Mule' in New Kingdom Egypt?," Göttinger Miszellen 13 (Göttingen: 1974). Bertha Porter, Rosalind L.B. Moss, Topographical Bibliography of Ancient Egyptian Hieroglyphic Texts, Reliefs, and Paintings: I. The Theban Necropolis, Part 1. Private Tombs (Oxford: Griffith Institute, 1970), 465. Hofmann, Fubrwesen und Pferdebaltung im alten Ägypten, 49-52.

${ }^{49}$ Alessandra Nibbi, "Some Remarks on Ass and Horse in Ancient Egypt and the Absence of the Mule," Zeitscbrift für ägyptische Sprache und Altertumskunde 106 (1979): 163-168.

${ }^{50}$ Kathryn M. Hansen, "Mules' of the 18th Dynasty," in Ancient Egypt, The Aegean and the Near East: Studies in Honour of Martha Rhoads Bell, ed. Jacqueline Sharon Phillips (San Antonio: Van Sicklen Books, 1997), 219-226.

51 Anthony Dent, Donkey: The Story of the Ass from East to West (London: Harrap Publishers Ltd., 1972), p. 35-37.

52 Hansen, "Mules' of the 18th Dynasty," 224-225.

${ }^{53}$ By 'paint', the current author means any colour combination that is made up of two colours covering the entire body, not the breed.
} 
compositional reasons: showing different coloured horses makes the composition more interesting for the viewer. It is therefore adamant to take these coat colours the way we classify them with a grain of salt. In many cases however, we will see that many coat colours are plausible, and are therefore a great example of a reflection of "reality," something the artisan observed, combined with his compositional creativity. The Egyptians took the concept of the animal and formatted it to their wishes (i.e. the function of the image within the unwritten 'rules' of imagery). It is neither possible, nor relevant, to specify what kind of painted horse is represented from the image alone, which is why neither tobiano, nor rabicano, sabino or any of the other paint-varieties are used in this article. The earliest examples of phenotypes responsible for this pattern are found on a horse in Kazakhstan (cal. 3654-3630 BC) and in Salzmünde, Germany (cal. 3368-3101 BC)..$^{54}$

The aforementioned preference for conceptual display is clearly visible in the way coat colours of horses are depicted. Despite the variety of coat colours, there is an apparent uniformity which can be explained by several factors. First of all, the horses' coat colour served as a significant attribute for a large part of the Eighteenth dynasty. This means that the variability is limited. Secondly, juxtaposing different coat colours creates a clear distinction between two or more horses. Thirdly, the artist was limited by a restricted colour palette and finally, he was affected by his desire to produce a pleasing decoration. ${ }^{55}$ Depictions based on naturalism and depictions conforming to the iconographic conventions are not mutually exclusive. Rather, the depiction of the concept of the horse is based on true form but also, to an extent, influenced by the artistic ways of the Egyptians. These two notions worked together, as will be demonstrated below.

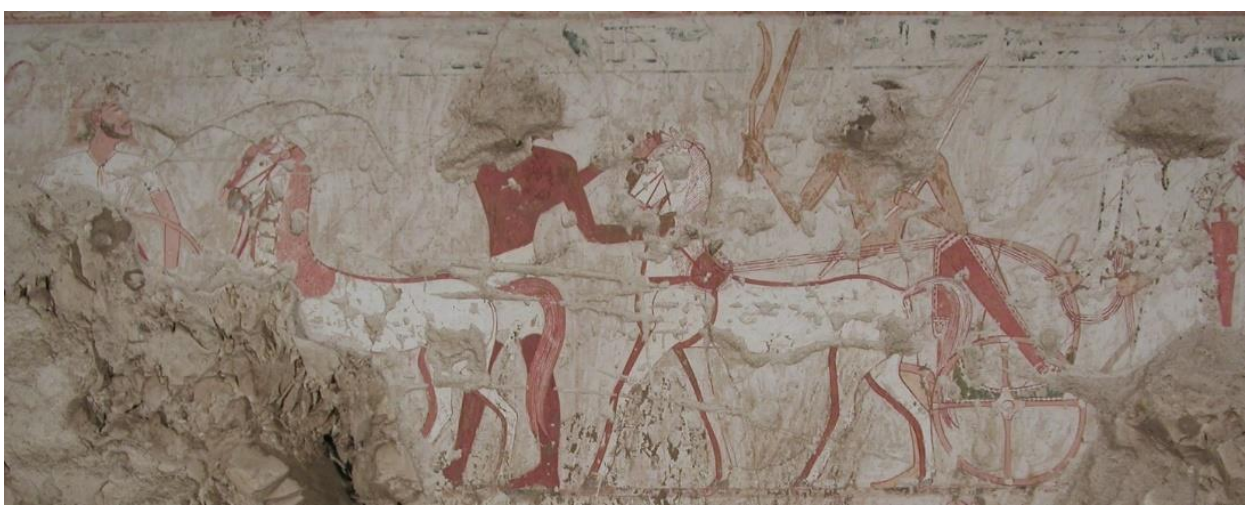

Fig. 9. Horses in TT86, tomb of Menkheperre-seneb.

Location: Sheikh Abd el-Qurna, Thebes. Photo: JJ Shirley.

\section{B. Grey and white}

In the Early and Mid-Eighteenth dynasty, we observe white painted horses in the tombs. As true white horses are a rarity, they were most likely what we call grey horses. This is supported by the details depicted in the Early Eighteenth dynasty, which often show grey horses with orange coloured manes, as we see for example in TT100, the tomb of Rekhmire (fig. 3) and

\footnotetext{
${ }^{54}$ Saskia Wutke, Norbert Benecke, Edson Sandoval-Castellanos et al., "Spotted phenotypes in horses lost attractiveness in the Middle Ages," in Sci Rep 6, 38548 (2016). https://doi.org/10.1038/srep38548: $1-9$.

55 William Stevenson Smith, A History of Egyptian Sculpture and Painting in the Old kingdom (New York: Hacker Art Books, 1978), 257.
} 
horses with a grey muzzle (fig. 9). Although this colouration might seem odd at first instance, it becomes more plausible when we remember that it takes grey horses six years to reach their maximum whiteness. During those years, an orange glow is present which turns greyer over time. This hypothesis is further strengthened by the horses in TT86, the tomb of Menkheperre-Seneb (fig. 9). This scene shows two pairs of horses, a grey and a chestnut, where both greys are depicted with an orange glow in their manes. The orange glow in the manes of the grey horse on the right is lighter than the glow of the horse in the first pair, suggesting this is an older horse. The artisan didn't necessarily realise he was depicting horses of a different age, but he did make the observation of the differently coloured manes. It has also been suggested that the orange manes might have been painted with henna, which of course is also possible. The Egyptians observed that white horses had a grey skin, and decided to depict that in the image by giving some horses a grey muzzle (fig. 9). The level of detail depicted in these images contributes to the naturalistic display, which in itself contributes to the ease of recognising the horse in a stage where the animal is still fairly new to ancient Egyptian society.

This level of detail becomes less frequent in the Mid-Eighteenth dynasty, and the white painted horses are less often depicted with manes with an orange glow and are instead rather depicted as completely white. This might have to do with artistic conventions, a change in style, and the fact that the horse is more known in society and the artisan does not have to meet the earlier requirements of naturalistic display in order for the observer to recognise the horse as such. Even though this lack of detail would suggest "true white" horses when taken at face value, this is not what is meant to be displayed. In fact, to the Egyptians, it is the same kind of grey horse as it was before: The image conveys the same message, namely that of "a white horse," albeit executed differently. It does not change the fact that the colour itself might have been observed correctly, it is the representation that is altered.

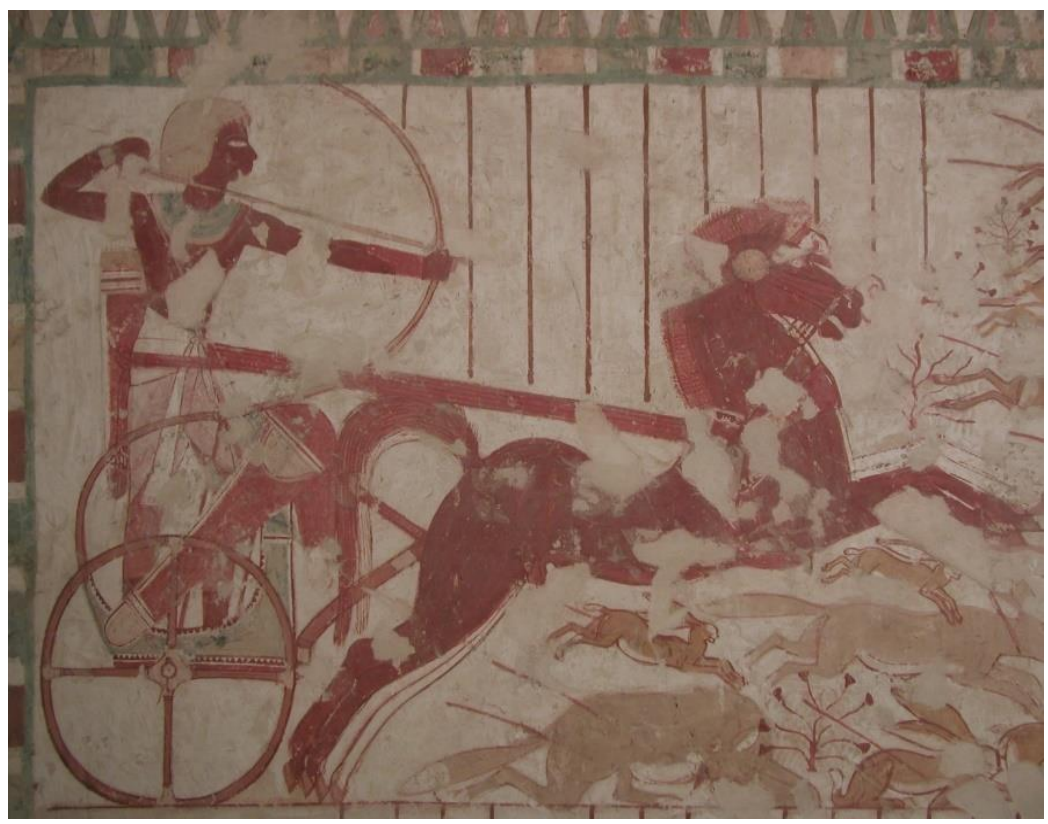

Fig. 10. Horses in TT56, tomb of Userhat.

Location: Sheikh Abd el-Qurna, Thebes. Photo: JJ Shirley. 


\section{Chestnut}

Most horses with identifiable coat colour are depicted as chestnuts. Most of them are sorrel chestnuts, occasionally there are some flaxen chestnuts and rarely liver chestnuts. As stated above, while these colours might conform to our standards in calling them different kinds of chestnuts, this does not mean that they all existed in ancient Egypt; it might also be due to artistic freedom. Some examples of sorrel chestnuts can be seen in TT56, the tomb of Userhat (fig. 10), TT100, tomb of Rekhmire (fig. 3) and the tomb of Horemheb (fig. 7). This colour is particularly popular during the Amarna period, where all identifiable coat colours show chestnut coloured horses. Since chestnut is so popular it seems fair to assume that this colour was the most common one in real life. Interestingly enough, the few horse remains from ancient Egypt that are preserved, also seem to be chestnut coloured horses. The horse found in the forecourt of TT71, tomb of Senenmut, shows a chestnut coloured tail (fig. 12). Additionally, the whips found in the tomb of Tutankhamun also consist of chestnut coloured horse hairs. This is the only case where archaeological remains can back up the results of this research unfortunately.

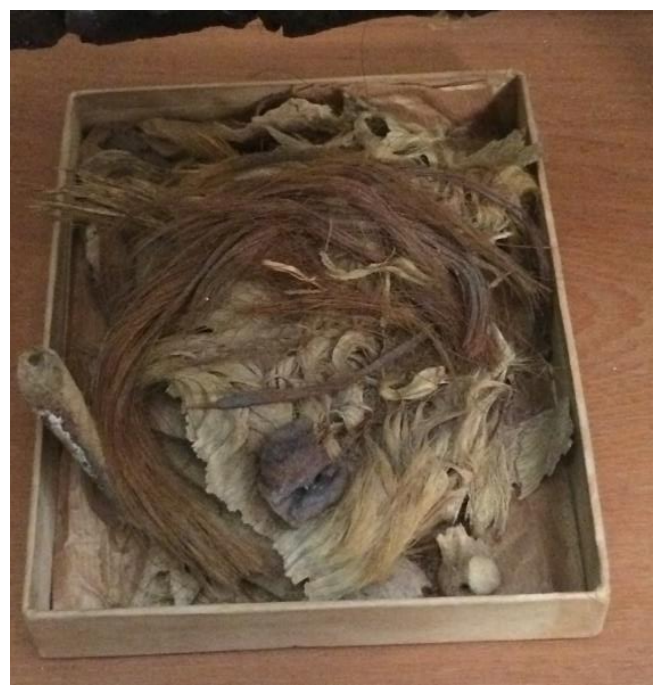

Fig. 11. Chestnut coloured hairs from the horse found in the forecourt of TT71. Location: Cairo Museum, Cairo. Photo: L.P.P. Delpeut.

\section{Bay}

The Mid-Eighteenth dynasty shows new colours, like the bays in TT 74, the tomb of Tjanuny (fig. 6). These bays are so far unique in the Egyptian depictions, from private tombs in ancient Egypt. Interestingly enough, all the horses show a bay-pattern but not all of them are possible in reality. Horses 1, 3, 4 and 5 show colours that are naturalistic: a dark brown bay with black manes and socks, a dark brown bay with black manes, a black horse and another dark brown bay with black manes. The two other horses however are of a lighter colour with darker manes. We could try to pinpoint the colour pattern, but it is likely that the artisan took the bay-pattern of 'coat + manes' and filled it out with this lighter colour for the sake of artistic variation and contrast to the darker horses. Even though the colour itself is not likely to have been real, he still stuck to the naturalistic bay pattern where the coat colour is one colour, and the corresponding manes are of a darker colour. The variety of colours in these horses also 
show the creativity of the artisan: no two horses are the same, and even if they are very similar, he would never position two similarly coloured horses next to each other. He has purposely chosen this sequence of horses in order to make the individual horses easily recognisable and to make the composition interesting for the visitor. He is showing what he has seen, as well as what he knows: In a way, he is showing his portfolio.

\section{E. Paint}

Three Theban tombs contain paint horses. They all originate from the Mid-Eighteenth dynasty and show a combination of grey + another colour. In TT69, the tomb of Menna, we see a beautiful illustration of a grey and chestnut painted horse, in front of a sorrel chestnut (fig. 2). This depiction is the perfect example of the artisan painting what he has seen, paying little attention to anatomical correctness. The colour combination and the patches are perfectly reliable, but the way the manes are coloured does not concur with reality. The manes are randomly coloured, not corresponding to the colour of the coat. For the Egyptians, this was not a problem, since the concept of "a horse with two colours" is still conveyed. In this sense, the rendering is ideal for the function of the image, as this level of anatomical correctness would not serve a purpose in the image. This does not mean that the image is unreliable: It shows a balance between depicting what the artisan knows, and depicting what is necessary for the image to convey what it is supposed to convey. TT78, the tomb of Horemheb shows grey horses with blue grey patches and light red patches, ${ }^{56}$ possibly corresponding to blue roan and cremello or palomino. Even though these colours do occur in reality in this case it is quite possible that the artisan was rather considering the 'interestingness' of the composition rather than a reflection of reality. He might however have seen these coats and patterns, and translated them into this composition where he tried to make it lively, interesting and the horses distinguishable from each other, as we have seen above in TT74, tomb of Tjanuny.

\section{The animal in motion}

Studying the horse in motion brings a whole new set of challenges along. When trying to classify representations of horses in motion into - for us - definable gaits, we immediately limit ourselves as what you see is not always what you get. In her MA-thesis, the author constructed a motion typology in order to define said gaits. While it was useful in studying the horses' movements, it was not sufficient to precisely define gaits. This does of course not mean that the Egyptians could not define them from the image alone. With the risk of stating the obvious, before the invention of the camera, it was difficult enough for artists to study the movements of horses, especially when they were going fast. The Egyptian artisans however still managed to clearly distinguish between "resting," "in motion" and "fast motion" within their images. These three labels are based on the position of the feet, the surroundings of the horse and chariot and the theme they were placed within (context). Studying the position of the legs alone does not help us identify gaits, although they might give an indication. Additionally, studying the surroundings of the horse (and chariot) is needed, for example, an unmounted chariot is unlikely to be going fast. Even slower movement is unlikely, especially if the groom(s) (or drivers) seems to be focused on something else, as in fig. 12. Finally, the context of the scene the horse is placed within might indicate what type of movement is being conveyed, as certain themes lend themselves for a specific type of motion where others do not. The most evident example here is hunting scenes, where the

\footnotetext{
${ }^{56}$ Annelies Brack, Arthur Brack, Das Grab des Harembeb: Theben Nr. 78 (Mainz am Rhein: Philipp von
} Zabern, 1980), pl. 9. 
horses' motion is without a doubt very fast. In most cases, it is a combination of at least two of these three factors that help us identify what type of motion is being conveyed within a scene.

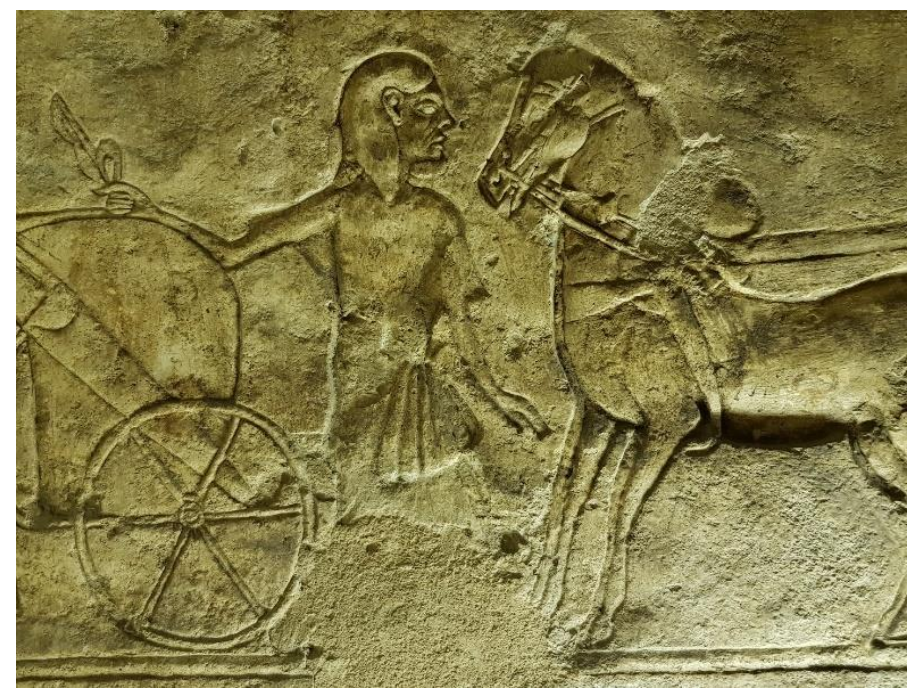

Fig. 12. Horses in the tomb of Meryra. Location: Amarna. Photo: C. Theunissen-Devens.

\section{A. Resting}

Resting horses are often displayed with all their legs on the ground or at least pointing towards the ground. In many cases the image still suggests movement, suggesting the vitality of the horses' character which is still being conveyed even when they are not moving forward. The position of the legs is not enough to determine that the horses are resting, as we will see below that at the beginning of the Eighteenth dynasty motion could also be displayed with all four feet still on the ground. This is why it is important to also look at surroundings as well as the context of the scene. Unmounted chariots, for example, are unlikely to be moving, especially if the groom is not even facing the horses and / or chariot, or if a groom is depicted standing in front of the horses, even holding the reins in some cases, such as in fig. 12. The front and hind legs of resting horses are often depicted close together, as is visible in the same figure. Here, the front legs are a little bent; in other cases, as for example in fig. 5 and 7 , the front legs are much more straight. Either way, the surroundings and the theme often support the fact that these horses are in fact not moving. The best example for this is visible in fig. 6, a relief from the tomb of Horemheb. The groom is leaning over the horse, and we can confidently conclude that these horses at not moving at all.

\section{B. In motion}

In the early Eighteenth dynasty, showing a quadruped in motion was usually done by showing the animal with their legs spread apart, but all feet on the ground. When the horse first appears into Egyptian imagery, some variety is introduced, and movement could also be shown by lifting one of their front legs in the air. Both these ways of showing motion are visible in fig. 13. These two types of displaying motion come back throughout the Eighteenth dynasty, but are particularly common in the Early Eighteenth dynasty. More examples can be observed in 
TT100, tomb of Rekhmire (fig. 3) and in TT86, tomb of Menkheperre-seneb (fig. 9). The slight knick at the knee of the horses in TT86 suggest that these horses are bending their leg in order to move. When discussing the type of movement, these horses clearly are not going very fast. Gallop, canter and even trot are excluded, and these horses therefore appear to be walking. The context in which these particular horses are displayed are tribute scenes, where one can imagine a large group of different kinds of goods and animals being led to the palace for inspection and administration for the king. This context does not lend itself for fast motion at all.

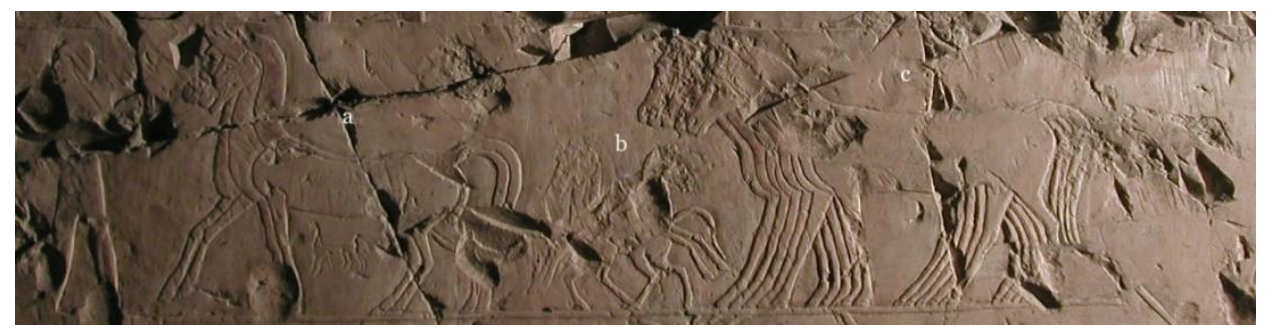

Fig. 13. Horses in TT123, tomb of Amenemhat. Location: Sheikh Abd el-Qurna. Photo: JJ Shirley.

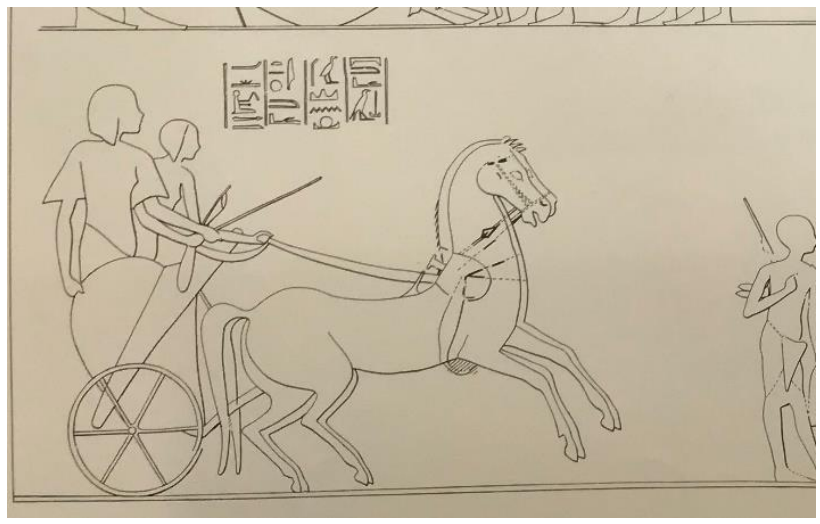

Fig. 14. Horses in the tomb of Mahu. Location: Amarna. Linedrawing: Norman de Garis-Davies, the Rock Tombs of El Amarna, Part IV. - The Tombs of Penthu, Mahu, and Others (London: Egypt Exploration Fund, 1906) pl. XXVI

It gets a little more complicated in scenes where the chariots are mounted, suggesting these horses are going at least a walking pace. Displaying faster movement seems to require two front legs in the air. Keeping in mind that the artisan was not preoccupied with the clear display of gaits, an attempt was made to recognise between 'walk' and any faster motion. An example of a pair of horses that might be in this category are the horses in the tomb of Mahu, chief of police, in Amarna (fig. 14). Both front legs are in the air, suggesting movement, and the scene description tells us the tomb owner is chasing criminals. This context is highly suggestive of fast motion. So is the chariot driver, who is holding the reins in one hand and a whip in the other. It is the combination of the positioning of the front legs, the context and setting which in combination convey fast motion in two dimensions. The same goes for the 
horses in TT49, tomb of Neferhotep ${ }^{57}$ and TT188, tomb of Parennefer ${ }^{58}$. Both these pairs of horses are from the Late Eighteenth dynasty, located in Thebes, and have their front legs in the air. Both scenes show the tomb owner using their chariots as a mode of transportation, suggesting movement. Seeing as there were so many ways to show a walking motion, it is safe to assume that this posture, of having two legs in the air, displays fast motion. Unable to distinguish between trot or canter, which is not the point: the artisan is conveying the concept of fast motion.

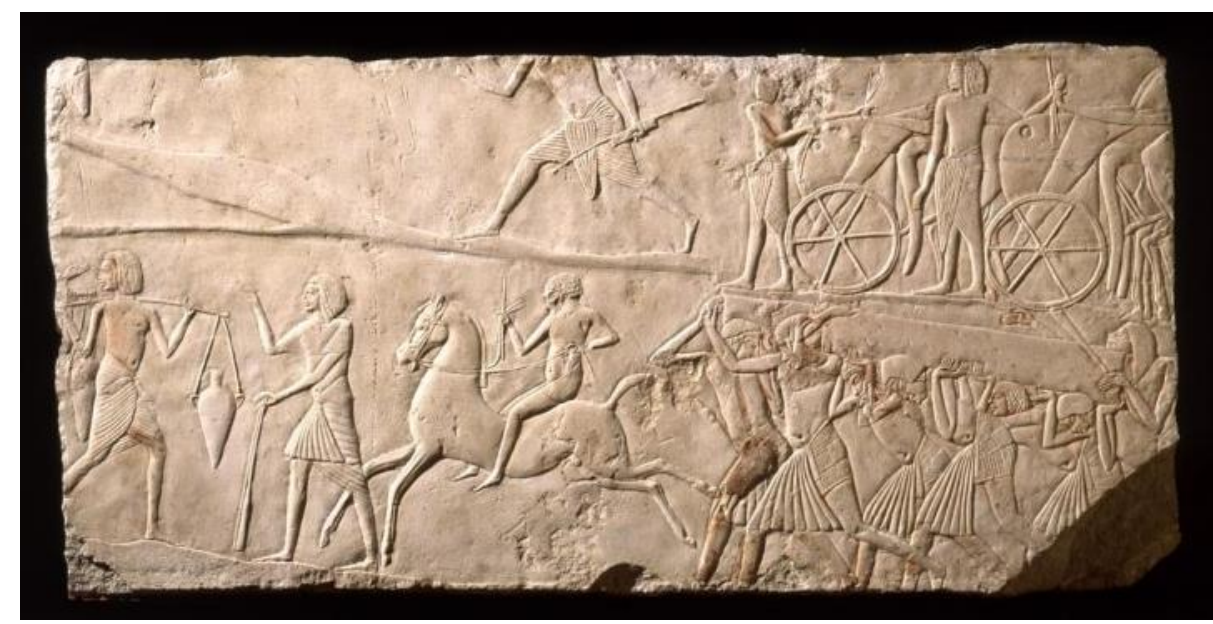

Fig. 15. Horse rider from the tomb of Horemheb in Saqqara.

Photo: Museo Civico Archeologico, Bologna. Accession number: Bologna 1889.

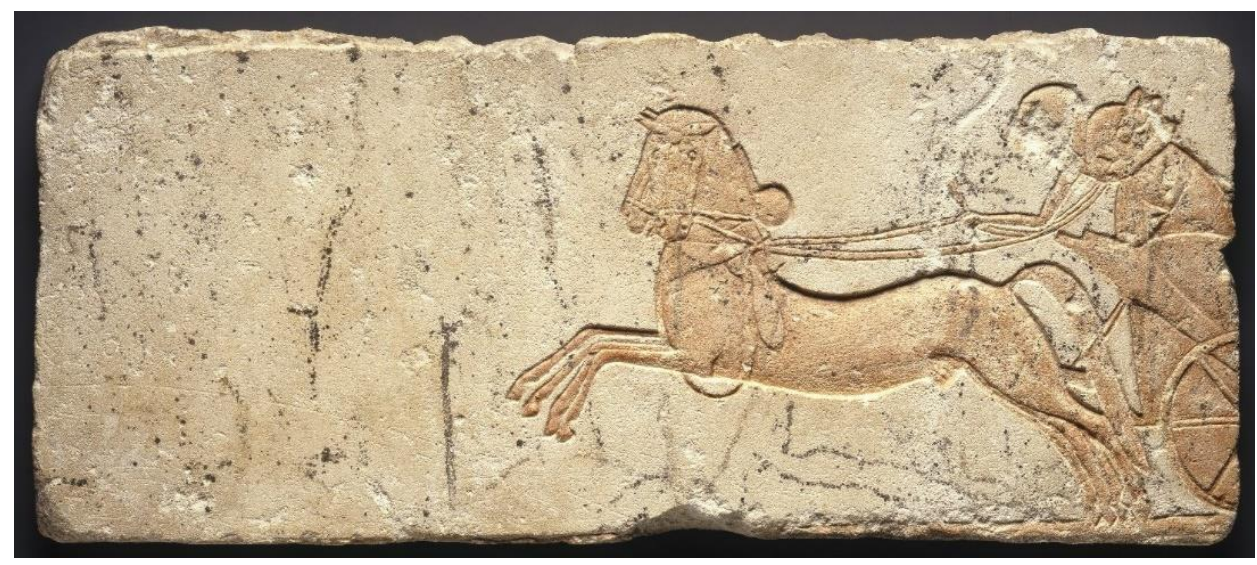

Fig. 16. Fast moving horses from the Amarna Period.

Photo: Brooklyn Museum, New York. Accession number: 60.28.

${ }^{57}$ Norman de Garis Davies, The Tomb of Nefer-Hotep at Thebes, Volume I (New York: Metropolitan Museum of Art, 1933) pl. XVI.

58 Friederike Kampp, Karl Joachim Seyfried, "Eine Rückkehr nach Theben. Das Grab des Pa-ren-nefer, Hoherpriester des Amun zur Zeit Tutanchamuns," Antike Welt 26 (1995): 325-342, pl. 26. 
Of the very few horse riding scenes we have, one occurs in a private tomb in Saqqara, namely in the tomb of Horemheb (fig. 15). This famous scene raises some motion-related questions. The legs are no indication whatsoever to define any range of movement, other than 'in motion'. According to Geoffrey Martin, it shows a military scout on horseback, and the surrounding scenes are taken from the military encampment. ${ }^{59}$ Only the horses' left front leg is touching the ground with the tip of the hoof, whereas the rest of the feet are in the air. Particularly interesting is the display of the hind legs, which only occurs in this scene. This might be simply explained by the fact that this is a scene of a horse being ridden instead of driven, and that usually the hind legs would not have space to actually move or depict them in this way. The impression this horse gives, is one of fast motion. Most legs are moving in the air, his tail is up high, and the rider is holding the reins as well as a whip. Looking at the context to help us determine the kind of movement is unhelpful. Interesting is the depth created by the overlap of the legs of the horses, being shown behind the surrounding people. It could mean that the horse is moving fast, passing them on their right side.

\section{B. Fast motion}

The most obvious representation of fast motion can be found in hunting scenes (fig. 10). The posture of said horses in art history is famously called the "flying gallop," as discussed by William F. Edgerton in the Journal of the American Oriental Society in $1936 .{ }^{60}$ Edgerton observed that it does not correspond to any real movement of the actual gallop ${ }^{61}$ and that it is likely inspired by the movement of other animals, "as the flying gallop is not an imaginary position, but a real one, belonging to dogs." 62 This is wonderfully illustrated in fig. 10, where the hares and other hunted desert animals are displayed moving in the same way. Whitney Davis suggests that the Egyptians might have been inspired by Aegean prototypes, and calls the flying gallop a "representation of vigorous motion." ${ }_{33}$ The term "flying gallop" however is a little off-point and inappropriate considering everyone perfectly understands that the horse is not in fact flying, but instead clearly going very fast. The artisan made that clear, without any doubt, which was exactly his intention. In order to assess this particular choice of posture for fast movement, the entire image composition needs to be addressed. It would be much easier to display fast motion in a setting where there is much more space for the scene, as in fig. 16. In the case of hunting scenes however, the artisan has to make choices as the space is limited. By lifting the horses' front legs high up in the air, the artisan is doing two things: he creates the impression of fast motion and he creates space underneath the horses to display other subjects involved in the hunting scene. Another example of a clear conveyance of fast motion can be seen on a limestone fragment from Amarna in fig. 17 and 18. Although these blocks are not within the primary scope of this article, it is a classic example of fast motion being conveyed by the horses having their front legs in the air, and their hind legs both stretched behind them. Additionally, these horses are not in front of a chariot and have space to stretch their necks forward, as they would when going very fast.

Not every horse with its front legs in the air is directly related to fast motion. Examples are visible in some Amarna tombs, where the king and sometimes the queen are depicted driving a chariot (fig. 19). These horses have their legs lifted in the air, but have them bent at

\footnotetext{
${ }^{59}$ Geoffrey Martin (ed), Tutankamun's Regent: Scenes and Texts from the Memphite Tomb of Horembeb (Leiden: Egypt Exploration Society, 2016) 36.

${ }^{60}$ William F. Edgerton, "Two Notes on the Flying Gallop," Journal of the American Oriental Society 56.2 (1936): 178-188.

${ }^{61}$ Edgerton, "Two Notes on the Flying Gallop," 179.

${ }^{62}$ Ibidem, 181

${ }^{63}$ Whitney Davies, The Canonical Tradition in Ancient Egyptian Art, 86.
} 
the knees, not stretched, like the classic flying gallop. In this case, the posture of the horses might not be intended to convey fast motion but have different reasons. It might have more to do with the king exerting power over such mighty beasts, while at the same time allowing some space underneath the horse for some people to be depicted. These compositional factors should not be excluded when discussing these types of scenes. The context of these scenes, namely that of a royal procession, in itself does suggest movement. This type of posture however, cannot directly be related to any type of movement considering "resting," "in motion" or "in fast motion." The current author intends to publish about this semi-rearing posture more extensively. ${ }^{64}$

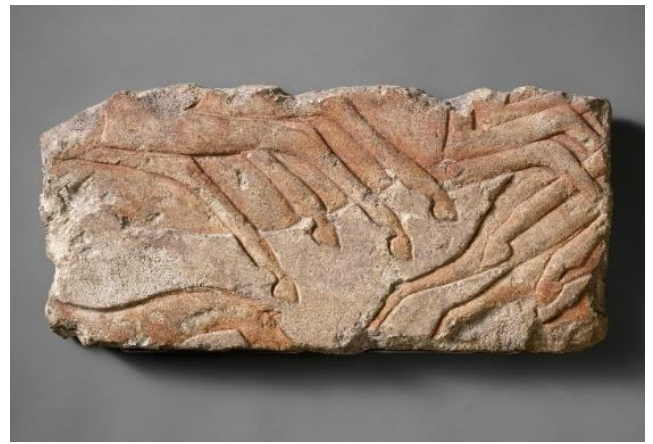

Fig. 17. Galloping horses from Amarna. Photo: Metropolitan Museum of Art, New York. Accession Number: 1985.328.17.

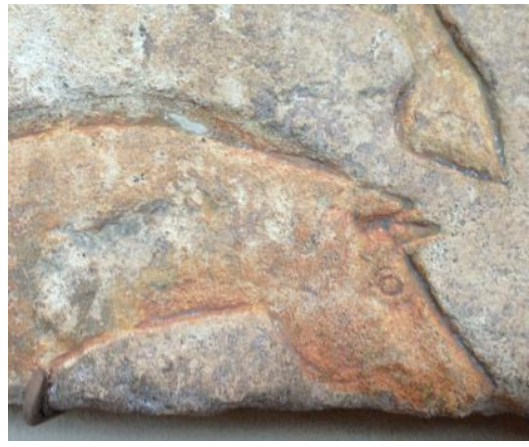

Fig. 18. Galloping horses from Amarna. Photo: Metropolitan Museum of Art, New York. Accession Number: 1985.328.17.

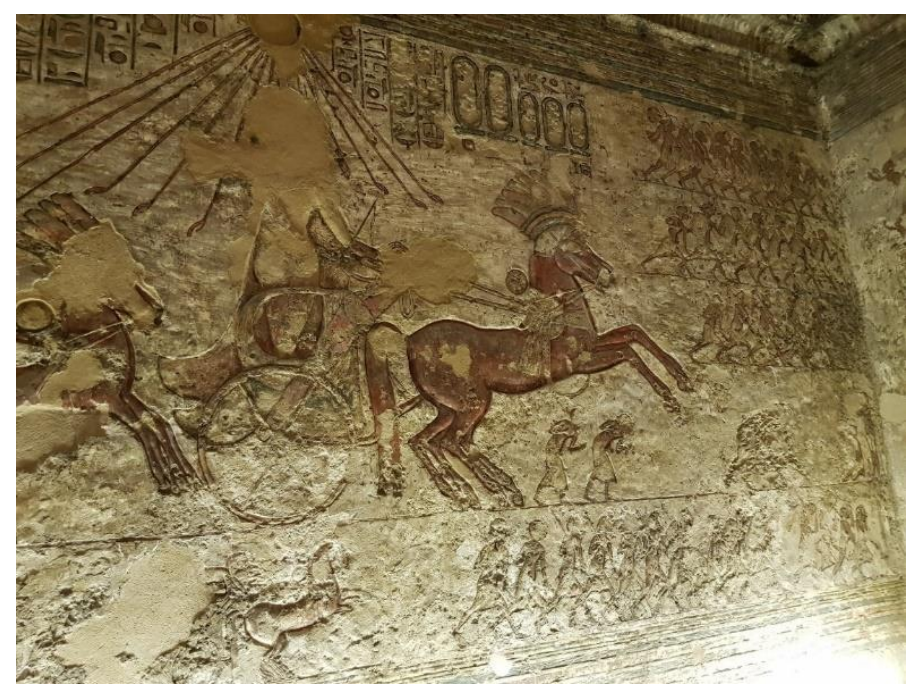

Fig. 19. Akhenaten on his chariot pulled by two horses in the tomb of Meryra. Location: Amarna. Photo: C. Theunissen-Devens.

\footnotetext{
${ }^{64}$ As this semi-rearing posture has been popular throughout history, I am looking for co-authors to
} write with. Please get in contact if you are interested. 


\section{Posture}

Some authors have discussed the posture of ancient Egyptian horses. Kathryn Hansen argues that the ancient Egyptian artwork, harness and chariots indicates the training of horses centred on collection, ${ }^{65}$ a backwards shift in the horse's balance. ${ }^{66}$ She argues that this shift in balance is precisely the position shown on ancient tomb and temple walls, ${ }^{67}$ using fig. 8 as an example of this. She supports her argument with archaeological remains of bits and additional pieces of harness used by the Egyptians, including sidelines and martingales. ${ }^{68}$ Jennifer Jobst rather argues that it is a "fixed head" phenomenon, and fears that the term "collection" is not an appropriate term to apply to ancient material considering its Eurocentric origin. ${ }^{69}$ In modern times, the extensive raising of the horses' head is called "absolute elevation," as discussed in Tug of War: "A horse ridden in 'absolute elevation' loses the connection through its back, and is characterized by disharmonious gaits such as an ambling walk, a trot with considerable 'throwing' of the front legs, and a canter that disintegrates to a four-beat gait with trailing hind legs." 70 Almost all horses are depicted with protruding chests, which remains a (visual) characteristic for chariot horses. One can ask however to what extent these images are a representation of how the ancient Egyptians trained their horses, and to what extent the image is simply a representation of the concept "chariot horse." There is doubtlessly some truth in the image, otherwise it would not have been shown this particular way.

Whichever interpretation on the position of the head one prefers, the protruding chest seems to be inextricably linked with chariot horses. An exception to the predominantly protruding chests can be found in TT123, the tomb of Amenemhat (fig. 13). The pair of horses on the left shows a pair of horses with protruding chests, whereas the group of 5 horses on the right display longer necks stretching forward. This observation was first made by horse-behaviourist and lieutenant-colonel of the Dutch cavalry Harry Kampen when I showed him the images. ${ }^{71}$ The pair of horses is being brought in as a team, which adds to the assessment of these horses being chariot horses. The other group, however, is a group of five horses in a different posture. This posture, as well as the fact that it's a group of five horses, might suggest that these are not chariot horses but instead are meant to display breeding horses. This is supported by the fact that these horses are displayed with udders, which clearly marks them as mares. Additionally, there are two foals depicted in front of them (fig. 13.b or fig. 23), probably conveying they belong to those mares. These are the only horses known so far that are juxtaposed to chariot horses in showing a different posture, and do therefore convey a clear distinction between chariot horses and breeding horses.

An interesting observation can be made in the tomb of Meryra in Amarna (fig. 20). The relief shows two horses eating or drinking from a trough. Their front legs seem to be hunching down towards the trough, and the hind legs are slightly bent at the knees. Despite the image unequivocally fulfilling its function in conveying the concept of eating or drinking, it is still worth focusing on this particular posture, which does not reflect a reliable image of how horses eat or drink. Horses do not have to bend their knees to reach the ground, let alone a

\footnotetext{
${ }^{65}$ Kathryn M. Hansen, "Collection in Ancient Egyptian Chariot Horses," Journal of the Ancient Egyptian Research Center in Egypt 29 (1992): 173-179.

${ }^{66} \mathrm{Ibidem}, 173$.

${ }^{67}$ Ibidem, 173.

${ }^{68}$ Ibidem, 173-179.

${ }^{69}$ Jennifer Jobst, personal communication June 2021.

${ }^{70}$ Gerd Heuschmann, Tug of War: Classical versus "Modern" Dressage (Whiltshire: The Crowood Press Ltd, 2018), 89.

${ }^{71}$ Lieutenant-colonel Harry Kampen, personal communication February 2018.
} 
trough, to eat or drink. A similar scene in a different tomb in the same necropolis (fig. 21) shows a more reliable rendering. Scenes of horses eating or drinking are rare, all together they appear only in three tombs. When comparing the horses in fig. 20 and fig. 21 to those in other scenes where they are resting or moving, we always see the bent hind legs and a great variety in how their front legs are shown. What seems to have happened here is that the artisan used a scene he was familiar with, namely "an animal eating or drinking," and inserted the horse into the scene without much regard of how horses actually stand when eating or drinking. As said before, this does not matter for the function of the image, but it is interesting nonetheless.

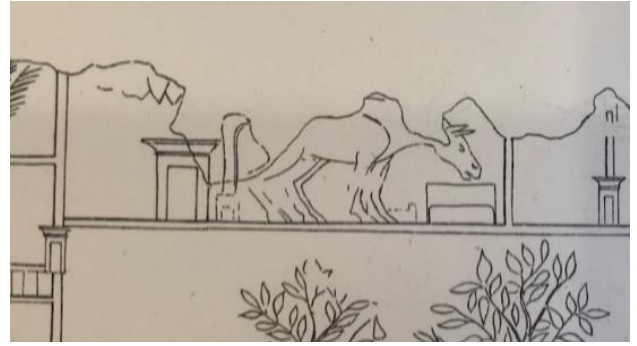

Fig. 20: Two horses eating or drinking from a trough in the tomb of Meryra. Location: Amarna. Line drawing: Norman de GarisDavies, The Rock Tombs of El Amarna, Part I. The Tomb of Meryra (London: Egypt Exploration Fund, 1903) pl. XXXII.

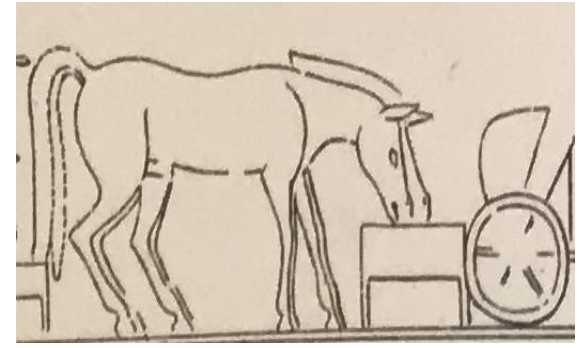

Fig. 21: Two horses eating or drinking from a trough in the tomb of Tutu. Location: Amarna. Line drawing: Norman de Garis-Davies, The Rock Tombs of El Amarna, Part VI. - Tombs of Parennefer, Tut and Ay (London: The Egypt Exploration Fund, 1908) pl. XX.

The same might have happened with the horse rider in the tomb of Horemheb (fig. 15). This article has already discussed the display of movement within the image, but this relief also deserves some comments regarding the posture and position of the rider. To our standards, the rider sits too far back. Nowadays, riders like to sit directly behind the withers as it is the most comfortable for them as well as the horse. This scene might indeed prove that the ancient Egyptians rode their horses sitting further backwards than we do. There is however an alternative interpretation. Sitting so far back is the way donkeys are ridden. Since horse riding was not very common in ancient Egypt, the artisan might not have been familiar with the exact way horses were ridden. He therefore took a motif he already knew, donkey riding, and 'translated' the concept of "riding" onto a new animal. A saddle blanket found with the remains of the horse found in the forecourt of TT7172 shows ropes to attach the blanket around the neck and around the girth. This would support the argument that horses were indeed ridden closer to the withers than this image shows. As this is the only surviving saddle blanket from ancient Egypt, it would not be appropriate to say that it is irrefutable evidence that horses were ridden a specific way.

\section{Behaviour}

The kind of scenes horses are depicted in usually show them at work or otherwise closely related to humans. There are no depictions of horses being tamed, trained, or bred, as taming was already done by the time they arrived in Egypt and to show the training and breeding of horses was not something that was appropriate within the Egyptian canon. We therefore do

\footnotetext{
72 Published in Lansing, Hayes, “The Museum’s Excavation at Thebes,” 15, fig. 17.
} 
not find a lot of scenes that show behaviour that is naturally displayed by horses. We do find a few instances however with displays of natural behaviour. Additionally, there are some scenes that show glimpses of classic horse behaviour, albeit human influenced, in scenes that deviate from the standard. Linda Evans summarises the importance of the study of animal behaviour when it comes to image studies: "Comparison of the behaviour of depicted animals with that of contemporary fauna allows an objective measure by which to judge how artists translated and transformed identifiable dynamic actions into two-dimensional images." 73 Additionally, she proposes that the behaviour exhibited by depicted animals provides a key by which to understand more fully both the representational method of Egyptian artists and the intended meaning of their images. ${ }^{74}$

A scene that stands out considerably is the scene in the tomb of an unknown owner in Saqqara (fig. 21). The complete limestone block shows three horses accompanied by at least four men. The horses seem to be completely out of control; these horses are not happy, and neither are their grooms. The middle horse has a wrinkle depicted on his upper lip, a classic sign that the horse is in distress. For horse owners and anyone dealing with horses regularly this scene feels taken from life: A horse getting out of control when being led by a rope. The artisan has created the impression of wildly moving horses by showing their feet going in different directions, their heads looking into various directions and their tails being far away from their bodies, instead of hanging halfway their lower hind legs, as we usually see. This impression is supported by the men trying to hold the horses down. The horse on the left is even being led by two ropes. The artisan made sure that the observers of the scene understood the masculinity of the horses, with all three horses' genital sex markers clearly displayed. Evans emphasises the importance of the study of genital sex markers of depicted figures, "since poses adopted by males and females some behaviours can differ markedly, while others may be exhibited by only one sex." 75 The discussed scene is a perfect example of this as the behaviour of these horses seems to be related to their masculinity. Their high tails, raised heads and wrinkled mouths cause for an aggressive, out of control impression. It seemed that the artisan was well aware of the behaviour of stallions among each other. Not only might the scene be something the artisan observed in real life, but he skilfully managed to display this kind of behaviour in two dimensions. However, as mentioned above, this type of scene is rather uncommon to find in a tomb and the fact that it appears seems to indicate a personal interest from the tomb owner.

Another rare example for the display of natural behaviour is visible in the aforementioned TT123, tomb of Amenemhat (fig. 23). Two foals are depicted standing on their hind legs, each facing another way, creating a dynamic image. The horses greatly overlap, but the scene conveys typical foal behaviour of play fighting, and should probably be interpreted as rearing opposite each other instead of next to each other. The foals do not wear any kind of harness, which makes sense for those experienced with horses: foals follow their mothers and a harness is not necessary. The artisan must have known this, either from seeing it in real life or obtaining the knowledge elsewhere. This dynamic image is a perfect example of nonhuman influenced behaviour depicted in two dimensions. Another example that deserves our attention in terms of natural behaviour is a limestone talatat block from Amarna (fig. 27). This is not from a private tomb, but illustrates perfectly how certain horse behaviour is conveyed in two dimensions. These horses are in front of a chariot, resting, and as we can see, one of them is scratching his head on the inside of his right leg. This is a very common

\footnotetext{
${ }^{73}$ Linda Evans, Animal Bebaviour in Egyptian Art: Representations of the Natural World in Memphite Tomb Scenes (Oxford: Aris and Phillips, 2010).

${ }^{74}$ Evans, Animal Behaviour in Egyptian Art, 11.

75 Ibidem, 15.
} 
sight in the horse world, and quite beautifully executed. The artisan must have observed this and deliberately chosen to depict it.

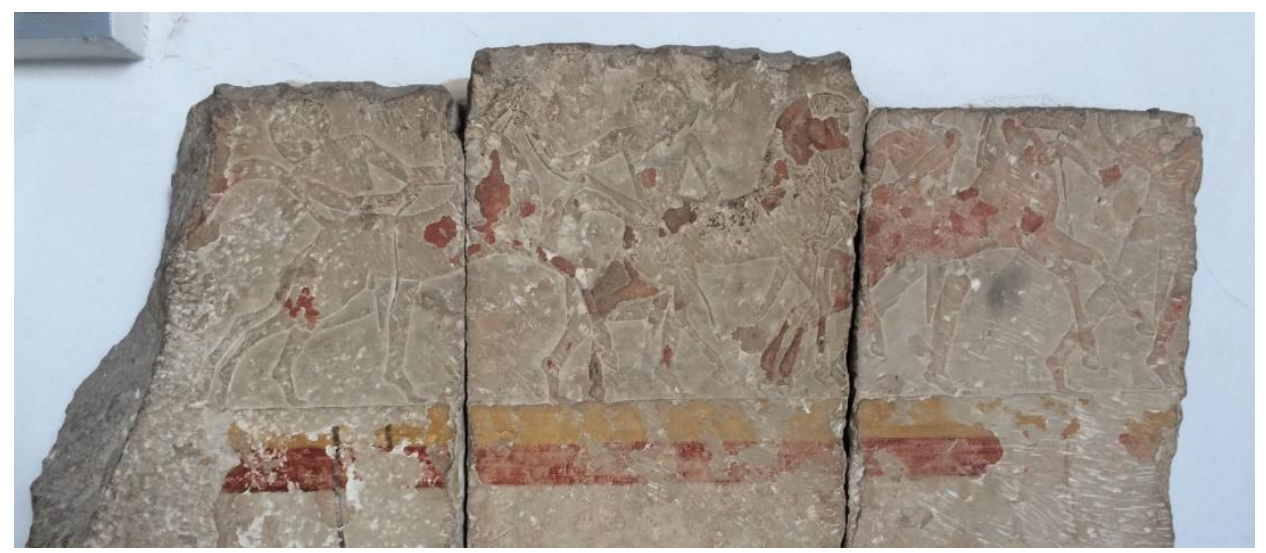

Fig. 22. Three stallions from an unknown tomb owner in Saqqara. Location: Cairo Museum, Cairo. Photo: L.P.P. Delpeut.

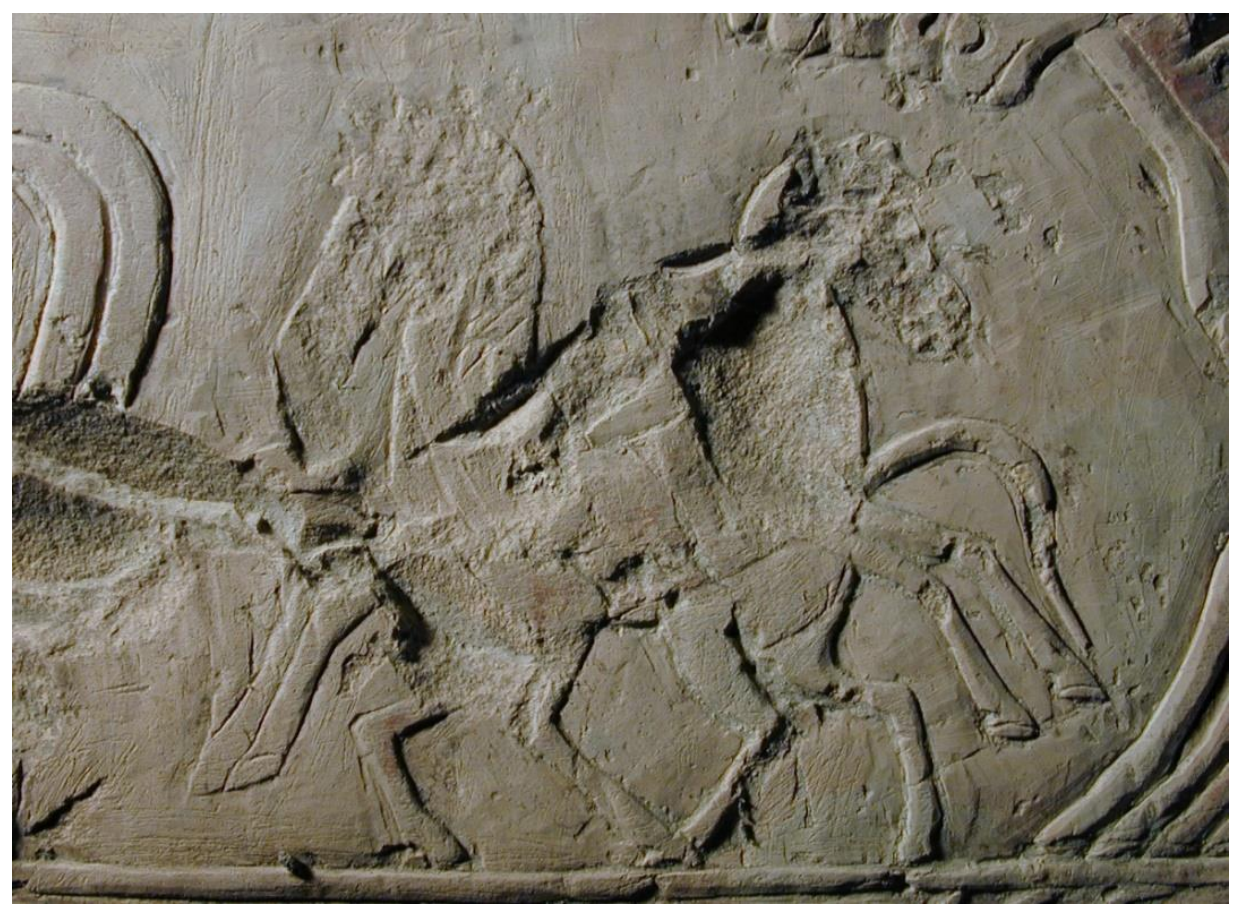

Fig. 23. Two foals in TT123, tomb of Amenemhat. Location: Sheikh Abd el-Qurna, Thebes. Photo: Dimitri Laboury. 


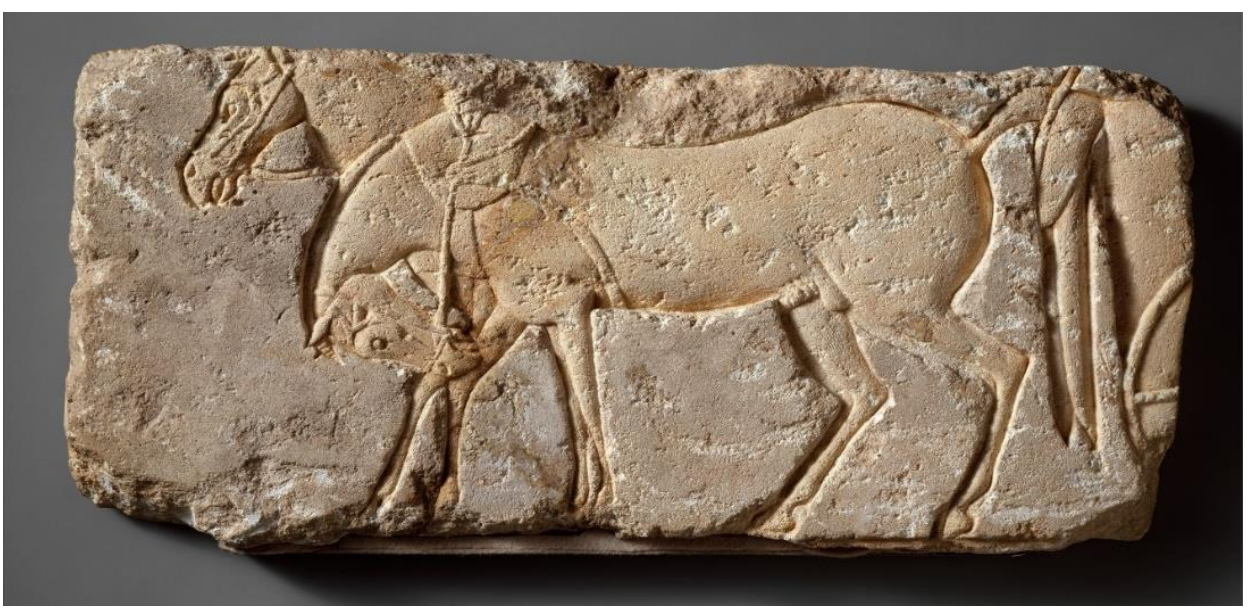

Fig. 24. Two horses in front of a chariot from Amarna.

Photo: Metropolitan Museum of Art, New York. Accession Number: 1985.328.18.

\section{Conclusion}

Overall, these observations prove the hypothesis that all images are based on reality, but the question is to what extent they convey reality. The Egyptian artisan made sure that the observer was able to recognise the horse from its visual characteristics by making sure it contained all the elements the observer needed to recognise the horse as such. The attributes they used to distinguish between different kinds of horses, coat colours, and the different types of motion are all used to convey the concept of what is being displayed: a chariot horse, a painted horse, a horse that is moving fast, and so on. These observations show that the artisan very carefully and deliberately chose the attributes to convey the concept of the horse and then specifying whatever he needed to for the image to function within the given context.

This paper has shown that in order to identify certain traits, such as movement, posture, behaviour and coat colour, one needs to keep in mind the setting of the horse (and chariot) as well as the context of the scene. When studied individually, one might lose the bigger picture. When assessing these images for 'realism' or 'naturalism', the artisans did a great job at displaying the horse in two dimensions within the Egyptian canon and decorum whilst still exploring their artistic freedom. While certain features might not live up to our standards, or our way of viewing the world, they were still able to convey whatever they wanted to in such a manner that the observer was able to recognise what was happening. There is a clear distinction for the artisan between "showing what they know" and "showing what they see" in ancient Egypt.

\section{References}

Baines, John. Visual and Written Culture in Ancient Egypt. Oxford: Oxford University Press, 2007.

Bertsch, Julia, Katje Broschat, Christian Eckmann. "Kairo, Ägypten. Die Goldblechbeschläge aus dem Grab des Tutankhamun.” iDaipublications 1 (2017): 54-57.

Bibby, Miriam. "The Arrival of the Horse in Egypt: New Approaches and a Hypothesis." In Current Research in Egyptology III: December 2001, ed. Rachel Ives, Daniel Lines, Christopher Naunton, Nina Wahlberg, 13-18. Oxford: Archaeopress, 2003. 
Stantis, Chris, Awara Kharobi, Nina Maaranen, Geoff M. Nowell, Manfred Bietak, Silvia Prell, Holger Schutkowski. "Who Were the Hyksos? Challenging Traditional Narratives Using Strontium Isotope (87Sr/86Sr) Analysis of Human Remains from Ancient Egypt." PLoS ONE 15(7) (2020): e0235414.

Bietak, Manfred. "Le Hyksos Khayan, son Palais et une lettre en cuneiforme." Comptes rendus des séances de l'Académie des Inscriptions et Belles-Lettres 2 (2010): 973-990.

Brack, Annelies Arthur Brack. Das Grab des Harembeb: Theben Nr. 78. Mainz am Rhein: Philipp von Zabern, 1980.

Chaix, Louis. “An Hyksos Horse from Tell Heboua.” In Archaeozoology of the Near East IV, ed. Marjan Mashkour, 177-186. Archaeological Research and Consultancy: Paris, 1998.

Heinz, Susanna Constanze. Die Feldzugsdartstellungen des Neuen Reiches: Ein Bildanalyse. Vienna: Verlag der Österreichischen Akademie der Wissenschaften, 2001.

Clutton-Brock, Juliet. Horse Power: A History of the Horse and the Donkey in Human Societies. Harvard: Harvard University Press, 1992.

Clutton-Brock, Juliet, Peter Raulwing. "The Buhen Horse: Fifty Years after Its Discovery (1958-2008)." Journal of Egyptian Archaeology 2 (2009): 1-106.

Davis, Whitney. The Canonical Tradition in Ancient Egyptian Art. Cambridge: Cambridge University Press, 1989.

Dent, Anthony. Donkey: The Story of the Ass from East to West. London: Harrap Publishers Ltd., 1972.

Edgerton, William F. "Two Notes on the Flying Gallop." Journal of the American Oriental Society 56.2 (1936): 178-188.

Evans, Linda. Animal Behaviour in Egyptian Art: Representations of the Natural World in Memphite Tomb Scenes. Oxford: Aris and Phillips, 2010.

Franco, Maurício M. "Quick method for identifying horse (Equus caballus) and donkey (Equus asinus) hybrids." Genetics and Molecular Research 15:3 (2016): 2-7.

de Garis Davies, Norman. The Tomb of Nefer-Hotep at Thebes, Volume I. New York: Metropolitan Museum of Art, 1933.

Gnirs, Andrea M. Militär und Gesellschaft: Ein Beitrag zur Socialgeschichte des Neuen Reiches. Heidelberg: Heidelberger Orientverlag, 1996.

Habachi, Labib. The Second Stela of Kamose, and His Struggle Against the Hyksos Ruler and His Capital. Glückstadt: J.J. Augustin, 1972.

Hansen, Kathryn M. "Collection in Ancient Egyptian Chariot Horses." Journal of the Ancient Egyptian Research Center in Egypt 29(1992): 173-179.

Hansen, Kathryn M. "Mules' of the 18th Dynasty." In Ancient Egypt, The Aegean and the Near East: Studies in Honour of Martha Rhoads Bell, ed. Jacqueline Sharon Phillips. San Antonio: Van Sicklen Books, 1997.

Harvey, Stephen. "Monuments of Ahmose at Abydos." Egyptian Archaeology 4 (1994): 3-5.

Hartwig, Melinda. Tomb Painting and Identity in Ancient Thebes, 1419-1372 BCE. Brussels: Brepols, 2004.

Heuschmann, Gerd. Tug of War: Classical versus "Modern" Dressage. Whiltshire: The Crowood Press Ltd, 2018.

Hofmann, Ulrich. Fubrwesen und Pferdehaltung im alten Ägypten. Bonn: Rheinische FriedrichWilhelms-Universität Bonn, 1989.

Hornung, Erik, Rolf Krauss, David A. Warburton. Ancient Egyptian Chronology. Leiden: Brill, 2006.

Kampp, Friederike. Die Thebanische Nekropole: Zum wandel des Grabgedankens von der XVII. bis zur XX. Dynastie. Mainz am Rhein: Verlag Philipp von Zabern, 1996. 
Kampp, Friederike, Karl Joachim Seyfried. "Eine Rückkehr nach Theben. Das Grab des Paren-nefer, Hoherpriester des Amun zur Zeit Tutanchamuns." Antike Welt 26 (1995): 325342.

Kitchen, Kenneth. "prd $>$ ptr $=$ "Mule' in New Kingdom Egypt?" Göttinger Miszellen 13.

Lansing, Ambrose, William C. Hayes. "The Museum's Excavation at Thebes." The Metropolitan Museum of Art Bulletin 32: 1, Part 2: The Egyptian Expedition 1935-36 (Jan. 1937): 4-39.

Littauer, Mary A., Joost H. Crouwel. Chariots and Related Equipment From the Tomb of Tut'ankhamün. Oxford: Griffith Institute, 1985.

Littauer, Mary A. Joost H. Crouwel. Selected Writings on Chariots and Other Early Vebicles, Riding and harness. Brill: Leiden, 2002.

Martin, Geoffrey, ed. Tutankamun's Regent: Scenes and Texts from the Memphite Tomb of Horemheb. Leiden: Egypt Exploration Society, 2016.

Moran, William L. The Amarna Letters. Baltimore: The Johns Hopkins University Press, 1992.

Nibbi, Alessandra. "Some Remarks on Ass and Horse in Ancient Egypt and the Absence of the Mule.” Zeitschrift fur Ägyptische Sprachen 106 (1979): 148-168.

Orlando, Ludovic, Alan K. Outram, e.a. "Ancient Genomes Revisit the Ancestry of Domestic and Przewalski's Horses.” Science 360: 6384 (April 2018): 111-114.

Porter, Bertha, Rosalind L.B. Moss. Topographical Bibliography of Ancient Egyptian Hieroglyphic Texts, Reliefs, and Paintings: I. The Theban Necropolis, Part 1. Private Tombs. Oxford: Griffith Institute, 1970.

Rommelaere, Catherine. Les Cheveaux du Nouvel Empire Égyptien: Origines, races, harnachement. Brussels: Connaissance de l'Égypte ancienne, 1991.

Schrader, Sarah A., Stuart Tyson Smith, Sandra Olsen, Michele Buzon. "Symbolic Equids and Kushite State Formation: A Horse Burial at Tombos.” Antiquity 92: 362 (2018): 383-397.

Schulman, Alan R. "Egyptian Representations of Horsemen and Riding in the New Kingdom." Journal of Near Eastern Studies 16: 4 (Oct., 1957): 263.

Sethe, Kurt Heinrich. Urkunden der 18. Dynastie: Historisch-Biographische Urkunden, dritter Band. Leipzig: Hinrichs, 1906).

—. Urkunden der 18. Dynastie: Historisch-Biographische Urkunden, erster Band. Leipzig: Hinrichs, 1927.

Simpson, William Kelly. The Literature of Ancient Egypt. Yale: Yale University, 2003.

Smith, William Stevenson. A History of Egyptian Sculpture and Painting in the Old kingdom. New York: Hacker Art Books, 1978.

Spalinger, Anthony J. War in Ancient Egypt: The New Kingdom. Oxford: Blackwell Publishing, 2005.

Wutke, Saskia, Norbert Benecke, Edson Sandoval-Castellanos et al. "Spotted phenotypes in horses lost attractiveness in the Middle Ages." Sci Rep 6, 38548 (2016). https://doi.org/10.1038/srep38548: 1-9.

Veldmeijer, André J., Salima Ikram, eds. Chasing Chariots: Proceedings of the First International Chariot Conference (Cairo 2012). Leiden: Sidestone press, 2013.

Veldmeijer, André J., Salima Ikram, eds. Chariots in Ancient Egypt: The Tano Chariot, a Case Study. Leiden: Sidestone Press, 2018.

Vernus, Pascal. "Réception linguistique et idéologie d'une nouvelle technologie: le cheval dans la civilisation pharaonique." In The Knowledge Economy and Technological Capabilities: Egypt, the Near East and the Mediterranean 2nd Millennium B.C. - 1st millennium A.D. Proceedings of a Conference held at the Maison de la Chimie Paris, France 9-10 December 2005, ed. Miriam Wissa, 1-46. Barcelona: Sabadell, 2009.

Webb, Peter. Imagining the Arabs: Arab Identity and the Rise of Islam. Edinburgh: Edinburgh University Press, 2014.

Weeks, Kent. “Art, Word, and the Egyptian World View.” In Egyptology and the Social Siences: Five Studies, ed. Kent Weeks, 59-81. Cairo: American University in Cairo Press, 1979. 